\title{
شروط الإحصان عند الفقهاء
}

بحث علمي يـ خُخصص الفته.

$$
\text { إعداد }
$$

عدنان بن عبدالالهه بن علي المالكي.

المهاضر بجامعة الباحة في قسمم الدراسة الإسلامية.

$$
\text { العام الجاهمي }
$$


(عدنان بن عبدالله بن على المالكي)

شروط الاحصان عند الفقهاء

$-1197-$ 


\section{مافمص البمث}

اهتم الفتهاء ببيان شــروط الإحصــــان في بابي حد الزنا والقذف؛ ليكون

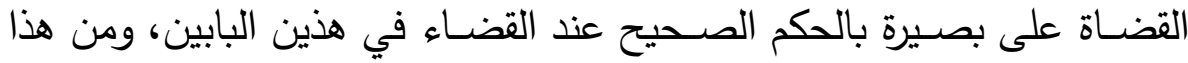

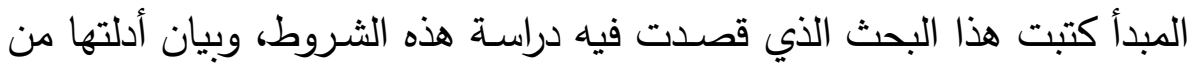
خلال هذا البحث الموسوم: ب(شروط الإحصان عند الفقهاء). وقبل البدء في دراســة هذه الثـروط، ذكرت تعريف الإحصــان في اللغة

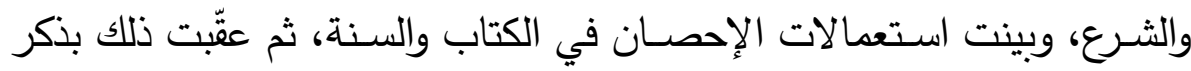
أنواع الإحصان عند الفقهاء، والمراد بكل نوع. وقد ذكرت الشروط المجمع عليها عند الفقهاء مع بيان مستتد ذلك وأدلته،

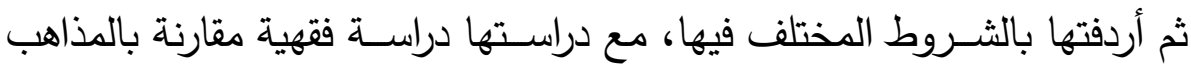

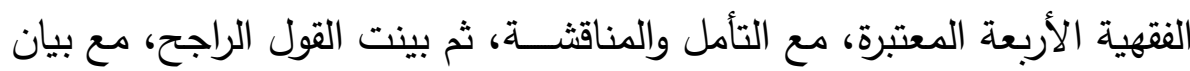

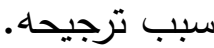

ولأهمية تحرير هذه الثـــروط، كتبت هذا البحث المســـتقل، ليكون عونا للقضاة وطلاب العلم عند دراستها وفهمها. وقد ظهر لي من هذا البحث دقة الثريعة الإسـلامية في إقامة الحدود، من خلال ترتيب الثروط لوجوبها؛ وذلك لِعظم المعصية في الزنا والقذف، وغيرهما مما يترتب عليه الحد.

$\$ \$$ 


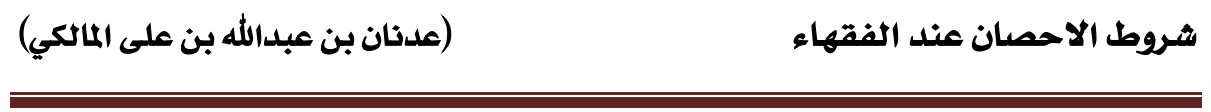

\section{Abstract}

The jurists were concerned with explaining the conditions for statutory in the two sections of adultery and slander. In order for the judges to have clear insight into the correct judgment when judging in these two chapters, and from this principle I wrote this research in which I intended to study these conditions, and show their evidence through this research marked: (the conditions of statistic among the jurists).

Before starting to study these conditions, I mentioned the definition of statistics in language and law, and explained the uses of statistics in the Book and the Sunnah.

The conditions agreed upon by the jurists were mentioned with an explanation of the evidence and evidence for that, then I supplemented them with the conditions in which they differed, along with its study of jurisprudence in comparison with the four recognized jurisprudential schools of thought, then clarified the most correct saying with an explanation of the reason for its weighting. And because of the importance of editing these conditions, I wrote this independent paper to be of help to judges and students of knowledge when studying and understanding them.

This research revealed the accuracy of Islamic law in establishing the hudud, by arranging the conditions for their obligation. And that is because of the greatness of $\sin$ in it.

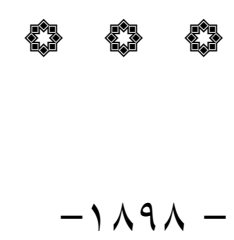


الحمد لله الذي هدانا لعبادته، وفطرنا على توحيده، وصـلى الله وسـلم على ألى نبينا محمد، أرسله رحمةً لمخلوقاته، وختم به جميع رسله وأنبيائه، وبعد:

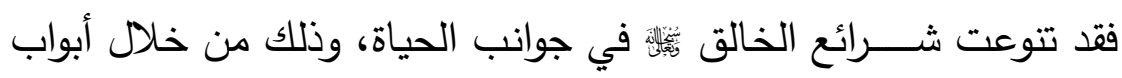

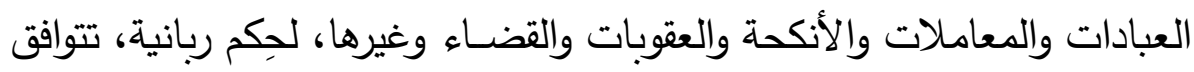

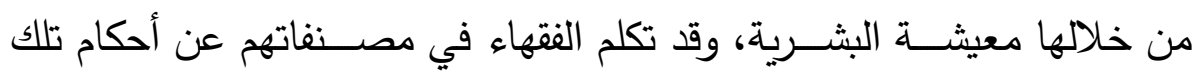

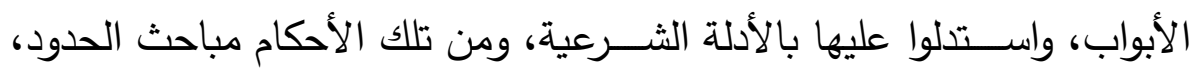

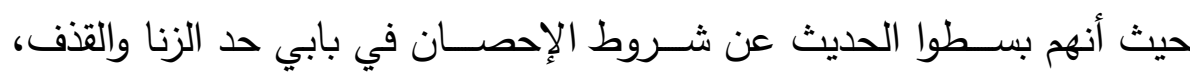

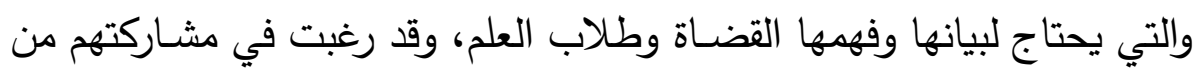
خلال هذا البحث الموسوم: بـ شروط الإحصان عند الفقهاء《.

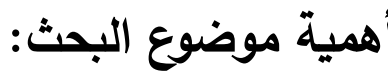

تظهر أهمية موضوع البحث في النقاط التالي: أولا: اهتمام الثـــريعة الإنـــلامية بحفظ الأعراض، حيث رتبت الحدود

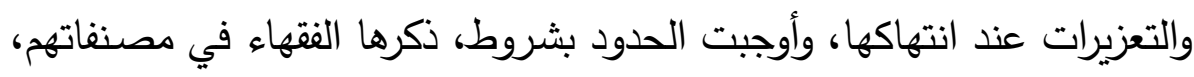
ومن ذلك هذه الثروط المقصودة بالبحث. ثانيا: أن الحدود قائمة على شروط دقيقة، تحتاج للجمع والتحرير ، وخاصة في ببابي الزنا والقذف. 
ثالثا: أن في إقامة الحدود الثـــرعية آثار حميدة في المجتمع، وتوجيه للنفوس إلى لفظ ما دعت الثــريعة لحفظها، ومما يعين على ذلك دراســة أحكام الحدود وشروط وجوب إقامتها، ليتحقق هذا الفضل والخير.

\section{ب أسباب اختيار الموضوع:}

تتنبع الكتابة في هذا الموضوع لأسباب، منها: أولا: علو منزلة الفقه في الدين، فعن معاوية بن أبي ســـفيان رضــــي الله

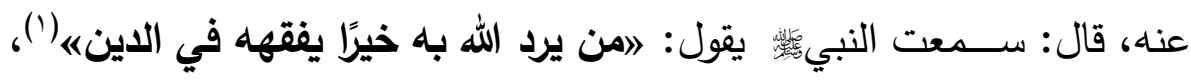

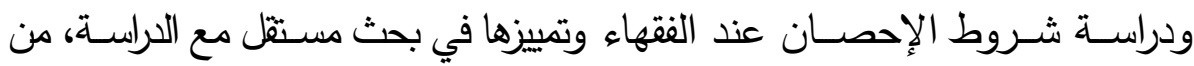
أفضل درجات الفقه، التي تستحق من طالب العلم تحصيلها وفهمها. ثانيا: حاجة القضاة وطلاب العلم لدراسة هذه الثروط دراسة فقهية مقارنة

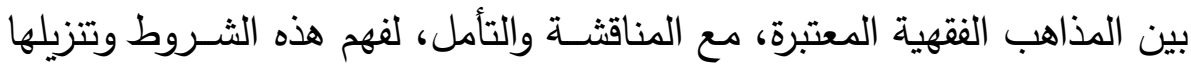

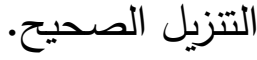
ثالثا: يقع أحيانا تداخل في معرفة شروط إحصـان الرجم وإحصـان القذف، مما تدعو الحاجة لجمعها في بحث مستقل؛ ليسهل دراستها والتثريق بينها.

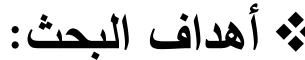

يهذف البحث في ختام كتابته أن يحقق غايات، منها:

$$
\text { ( ( ) أخرجه البخاري(ح (V))، مسلم(ح • • • ). }
$$


أولا: بيان المراد بالإحصان في اللغة والشرع، ودلالاته في الكتاب والسنة.

ثانيا: معرفة شـروط الإحصــان المتفق عليها والمختلف فيها في بابي حد

ثالثا: دراسة شروط الإحصان المختلف فيها بين الفقهاء دراسة مقارنة، مع بيان أدلة كل قول وتأملها ومناقثة ما يدعو ذلك؛ لمعرفة القول الراجح.

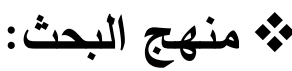

حرصت في كتابة هذا البحث الاعتناء بمبادئ منهجية، منها: أولا: إذا قُلت: الدذاهب الفقهية الأربعة، فأقصـــــ المذاهب الفقهية الأربعة المعتبرة: الحنفي والمالكي والثافعي والحنبلي.

ثانيا: إذا قُلت: اتفقت المذاهب الفقهية الأربعة، فأقصد اتفاق القول المعتمد

$$
\text { في هذه المذاهب. }
$$

ثالثا: لا أنص على الإجماع في المسألة إلا إذا نص العلماء على ذلك. رابعا: أعزو الآيات القرآنية، وذلك بذكر اسم السورة ورقم الآية.

خامسـا: أُخرج الأحاديث النبوية من بعض مصــادرها المعتمدة، فإن كان الحديث في الصحيحين أو أحدهما، فإني أكتفي بتخريجه منهما أو من أحدهما،

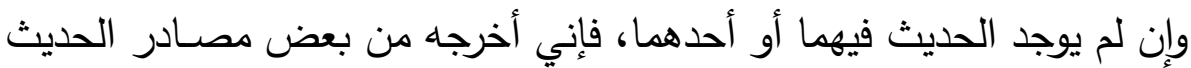

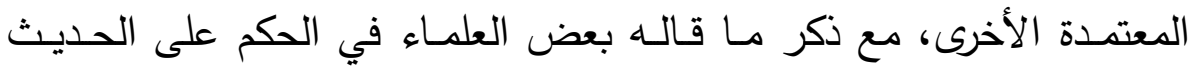




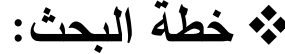

يثـــتمل البحث على: مقدمة، ومباحث، وخاتمة، وبيان ذلك على النحو

التالي: - n

أولا: المقدمة، وفيها: أهمية موضـــوع البحث، وأســـباب اختياره، وأهدافه،

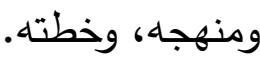

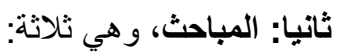

$$
\text { المبحث الأول: تعريف الإحصان. }
$$

المبحث الثاني: شروط الإحصان في باب حد الزنا. وفيه مطلبان:

المطلب الأول: شروط الإحصان المتقق عليها في باب حد الزنا.

المطلب الثاني: شروط الإحصان المختلف فيها في باب حد الزنا.

المبحث الثالث: شروط الإحصان في باب حد القذف. وفيه مطلبان:

المطلب الأول: شروط الإحصان المتقق عليها في باب حد القذف.

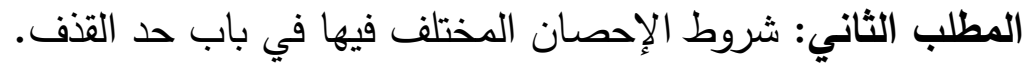

ثالثا: الخاتمة، وفيها: أبرز نتائج البحث.

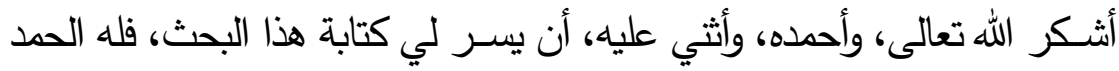

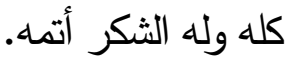

ثم أشـكر وأدعو من أسـدى إليَّ رأيًا، أو قدم لي معروفًا، فعن أبي هريرة

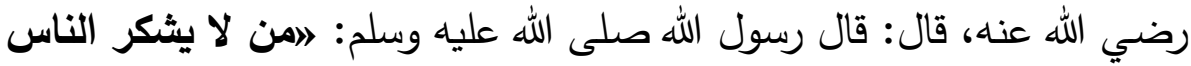

لا يثكر اللهه (').

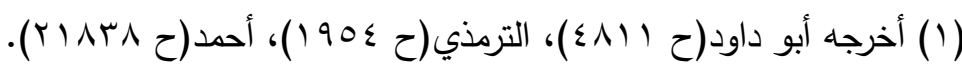

$$
\begin{aligned}
& -19 \cdot r-
\end{aligned}
$$


وعن ابن عمر رضي الله عنهما، قال: قال رسول الله صلى الله عليه وسلم:

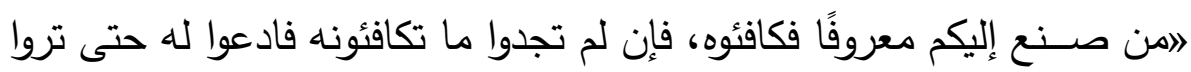

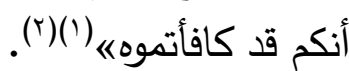

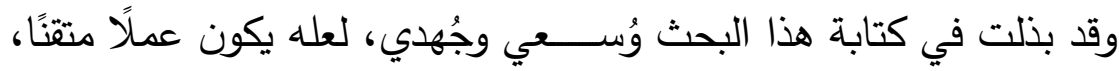

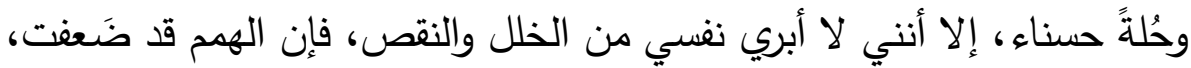

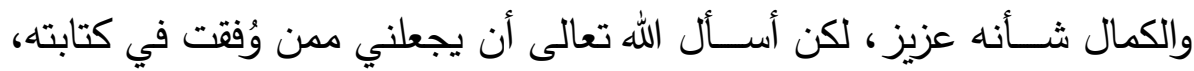

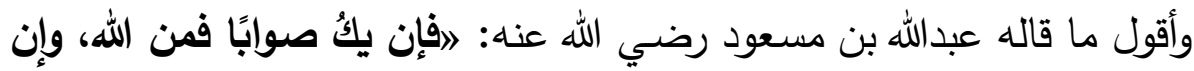

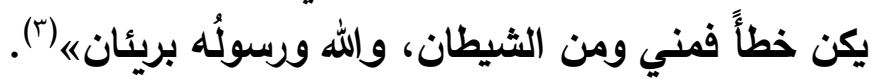

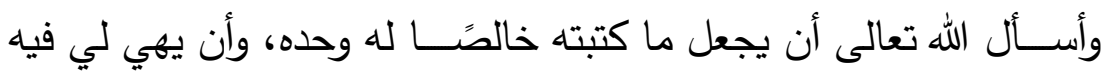

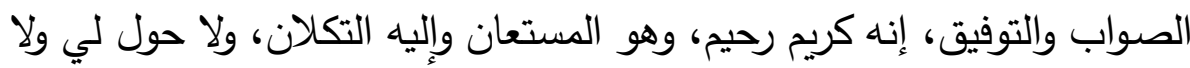

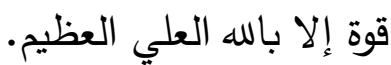

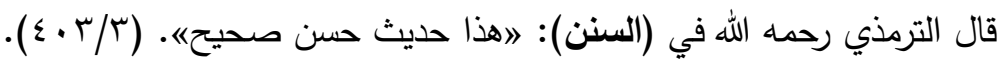

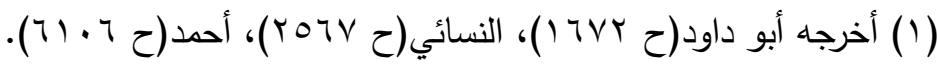

قال الحاكم رحمه الله في (المستـرك): اهذا حديث صحيح الإسناد على شرط الثنيخين ولم

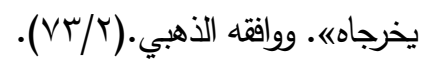

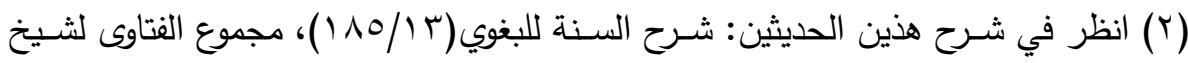

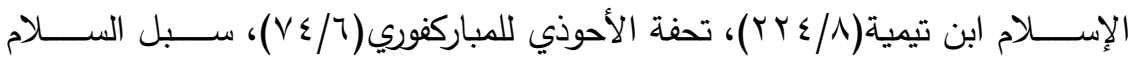

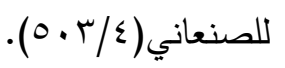

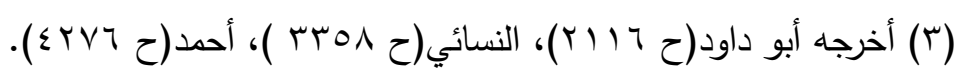

قال الحاكم رحمه الله في(المســترك) : (هذا حديث صــحيح على شـرط مسـلم، ولم

$$
\text { يخرجاه《• ووافقه الذهبي.(r/ (197). }
$$




\section{المبشث الأول \\ تعريف الإمصان.}

الإحصان في اللغة:

حصُـن المكان يحصُـن حصــانة، فهو حصـين: مَنُع، وأحصـنـه صـاحبه

وحصنـه. والحِصن: كل موضـع حصين لا يوصل إلى جوفه، وجمعه حصون.

وحصـن حصـين: من الحصـانة. وحصـنت القرية، إذا بنيت حولها، وتحصـن العدو : إذا دخل الحصـــن واحتمى بـه. ودرع حصـــين وحصــــينة: محكمة، والحِصـان: القرس العتيق. قيل سـي بذلك؛ لأن ظهره كالحصـن لراكبه، ثم كثر ذلك حتى سمي كل ذَكر من الخيل حصـانا وإن لم يكن عتيقا. والحَصـان: المرأة العفيفة، وأحصن الرجل: تزوج(').

\section{خ الإحصان في الثرع:}

الإحصان اسم يقع على معان مختلفة، غير ما كان الاسم لها في اللغة(؟)، حيث أن الفقهاء بينوا شروط الإحصان في باب حد الزنا، الذي يجب فيه الرجم، وباب حد القذف الذي يجب فيه الجلد.

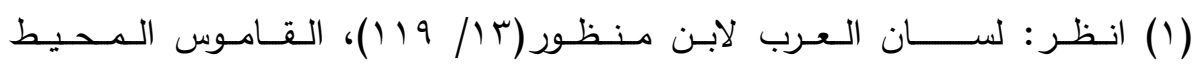

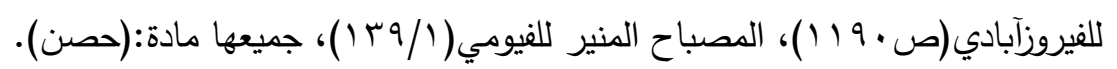

(r) (r) أحكام القرآن للجصاص(r/r) ( 9 ). 


$$
\begin{aligned}
& \text { (عدنان بن عبدالله بن على المالكي) }
\end{aligned}
$$

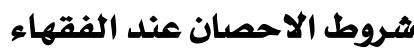

$$
\begin{aligned}
& \text { لكن من تعريفات الإحصــان في كتب التعريفات الاصــطلاحية: هو أن }
\end{aligned}
$$

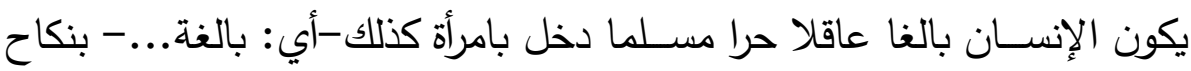

$$
\begin{aligned}
& \text { صحيح') (1) } \\
& \text { وعُرف أيضا بأنه: العفة وتحصين النفس من الوقوع في الحرام(†). } \\
& \text { والإحصــــان في كتاب الله ولغـة العرب واقع على معـان كلها راجع إلى إلى } \\
& \text { الامتتاع(r)، كما سيأتي بيانه في المطلب التالي. }
\end{aligned}
$$

\section{\%}

$$
\text { ( (1) التوقيف للمناوي(ص • ؟). }
$$

(ץ) التبيهات المستنبة للقاضي عياض(r/ Tov).

$-19.0-$ 


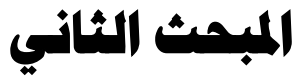 \\ شروط الإمصان في باب حد الزنا.}

شـرع الله تعالى حد الزنا، وهو يختلف فيه المحصـن عن غيره، فأما غير

المحصن فحده الجلد، وأما المحصن فحده الرجم، حيث جاء في (المغني): الأن

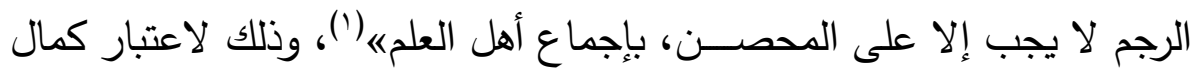

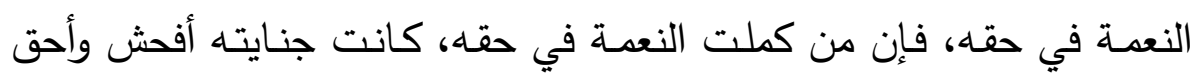

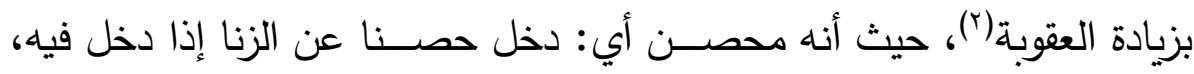

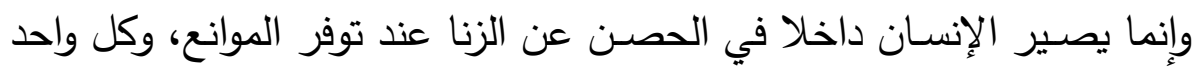

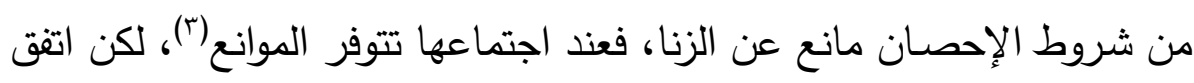

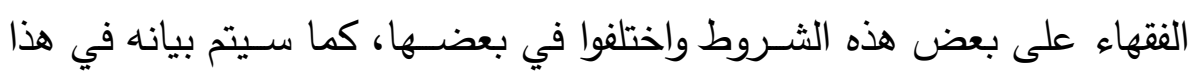

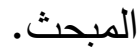

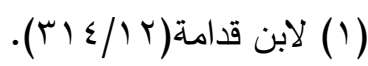

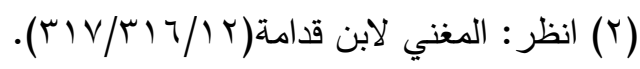

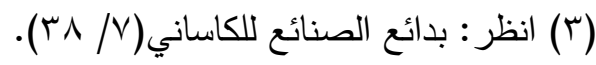

$$
\begin{aligned}
& -19.7-
\end{aligned}
$$




\section{المطب الأول \\ شروط الإمصان المتفق عليها في باب حد الرزنا.}

$$
\begin{aligned}
& \text { الثرط الأول والثاني: أن يكون بالغا عاقلا. }
\end{aligned}
$$

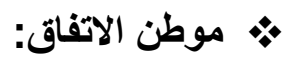

$$
\begin{aligned}
& \text { اتفقت المذاهب الفقهية الأربعة على أن من شــروط الإحصـــان في باب } \\
& \text { الزنا، البلوغ والعقل، حيث جاء في: (الإقتاع): لاولا يثبت عند الجميع إحصــان }
\end{aligned}
$$

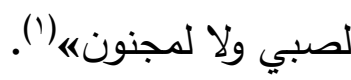

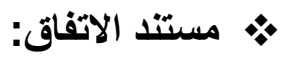

$$
\begin{aligned}
& \text { يستند هذا الاتفاق إلى أدلة، منها: } \\
& \text { (1) عن عائشة، عن النبي صلى الله عليه وسلم، قال: لارفع القلم عن ثلاث: } \\
& \text { عن النائم حتى يستيقظ، وعن الصغير حتى يكبر، وعن المجني المنون حتى يعقل }
\end{aligned}
$$

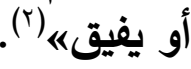

$$
\begin{aligned}
& \text { (Y) اعتبر العقل لكمال النعمة، فإن من كملت النعمة في حقه، كانت جنايته } \\
& \text { أفحش وأحق بزيادة العقوبة، والنعمة في العاقل البالغ أكمل(ّ). }
\end{aligned}
$$

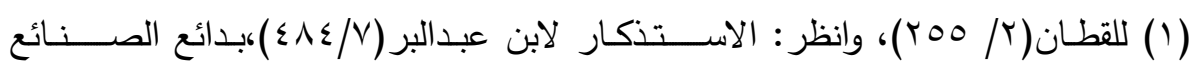

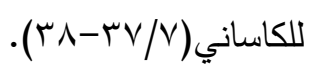

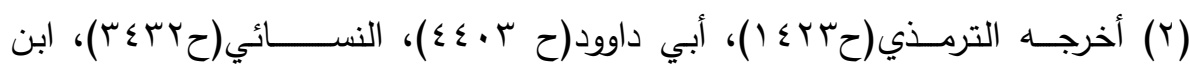

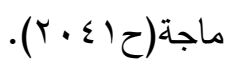

$$
\begin{aligned}
& \text { قال الحاكم في (المستدرك): 》هذا حديث صـحيح على شـرط الثـيخين، ولم يخرجاه《. }
\end{aligned}
$$

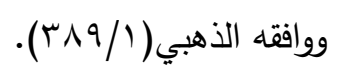

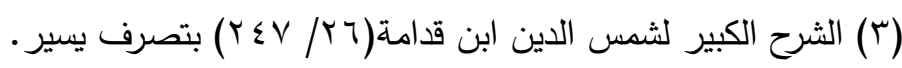

$$
\begin{aligned}
& -19 \cdot V-
\end{aligned}
$$


(T) أن للزنـا عاقبـة ذميمـة، والعقل يمنع عن ارتكاب ما لـه عاقبـة ذميمـة،

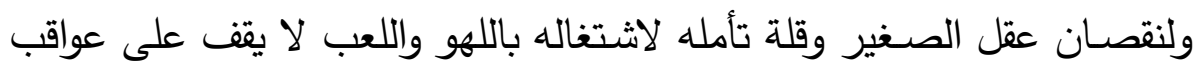
الأمور فلا يعرف المحمود من المذموم(') الثرط الثالث: أن يكون حرا، فلا يكون محصنًا من نكح أمة. •• موطن الإجماع: أجمع العلماء على أن من شروط الإحصان في باب الزنا

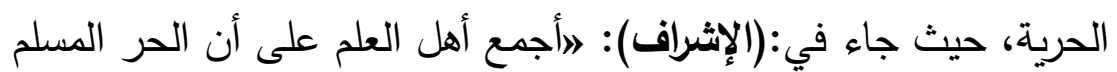

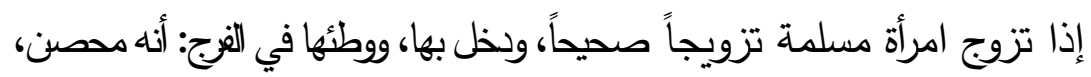
يوجب عليه وعليها، إذا كانت حرة، وزتيا: الرجمهاه (r).

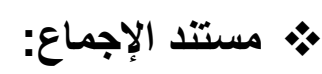

يستتد هذا الإجماع إلى أدلة، منها:

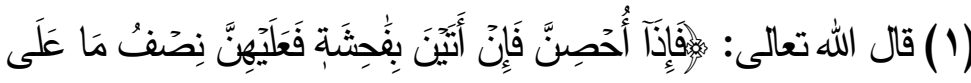

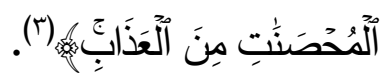

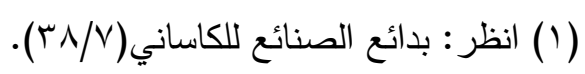

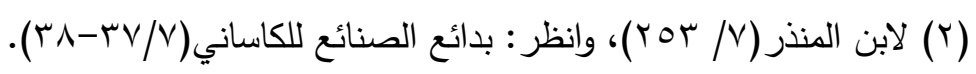

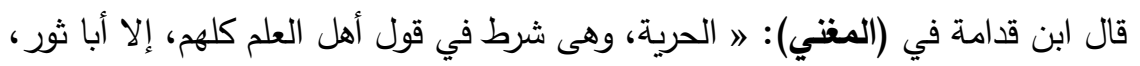

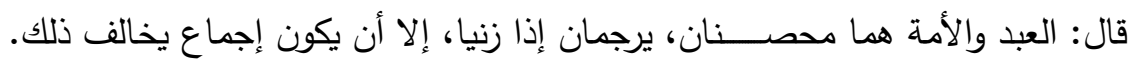

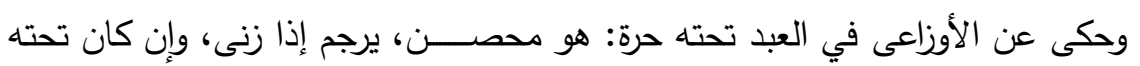

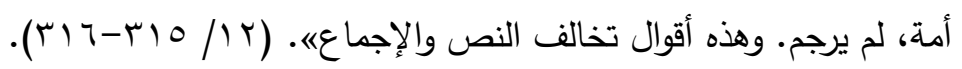

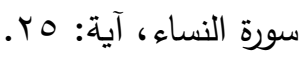




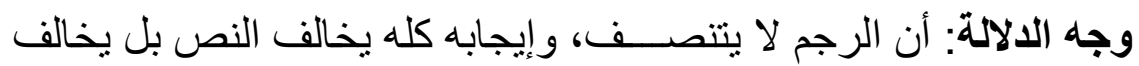

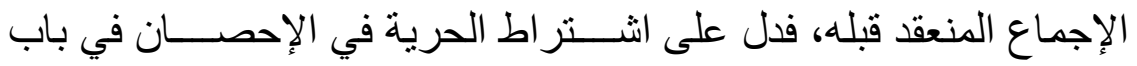

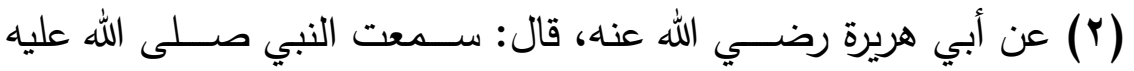

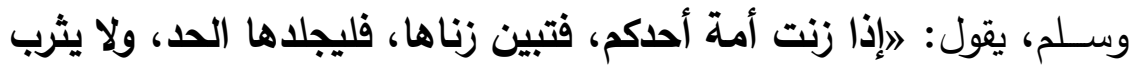

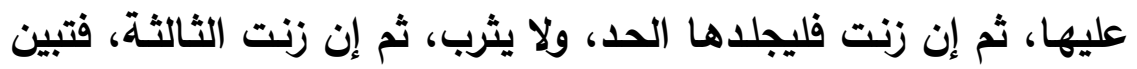

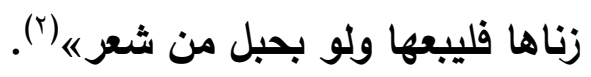
وجه الدلالة: أن في الحديث دليل على أن العبد والأمة لا يرجمان ســـاء

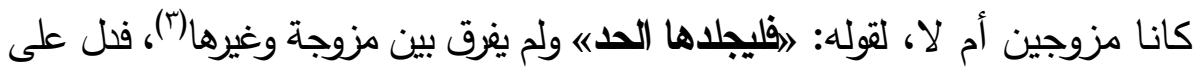
اشتراط الحرية للإحصان في باب الزنا.

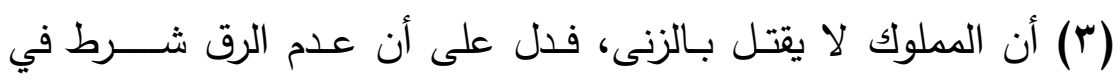

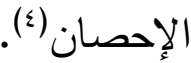
الشرط الرابع: أن يكون الوطء في نكاح، فلا يحصل الإحصـان في التسري ولا

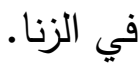
•• موطن الاتفاق: اتفقت المذاهب الفقهية الأربعة على أن من شروط الإحصان

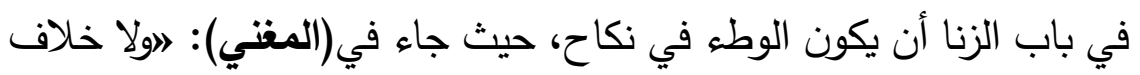

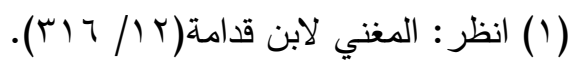

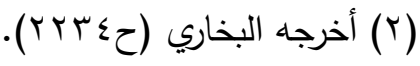

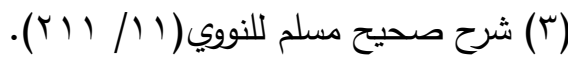

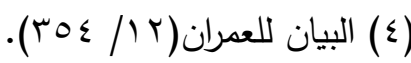


بين أهل العلم، في أن الزنى، ووطء الثبهة، لا يصير به الواطىء

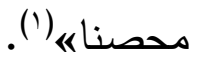
مستند الاتفاق: يستند هذا الاتفاق إلى أدلة، منها:

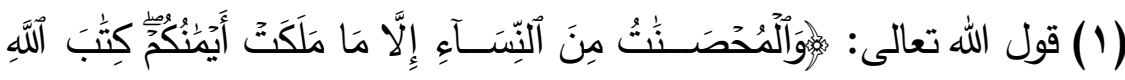

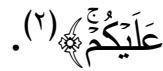

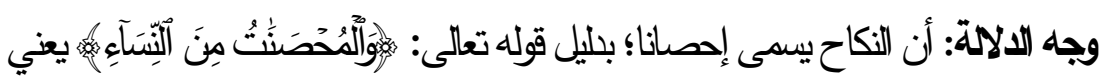

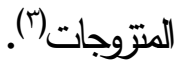
(Y) أن التسـري لا يحصـل به الإحصــان؛ لكونه ليس بنكاح ولا تثبت فيه

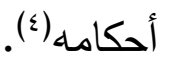

(r) أن حكمة الثـارع اقتضت وجوب حد الزنى على من كملت عليه نعمة

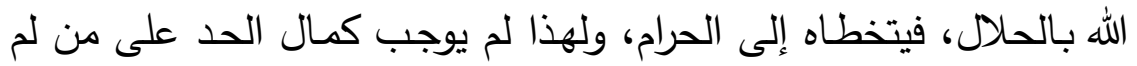
يحصن، واعتبر للإحصان أكمل أحواله: وهو أن يتزوج بالحة الحرة، دون التهال التسري

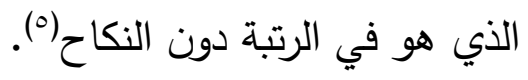

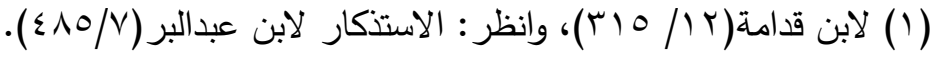

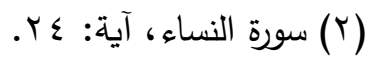

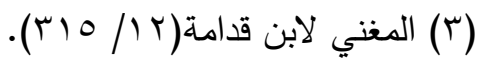

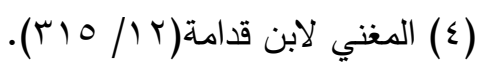

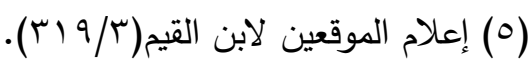

$$
\begin{aligned}
& -191 \cdot-
\end{aligned}
$$


الثرط الخامس: أن يكون الوطء في نكاح صحيح، فلا يحصل الإحصان في

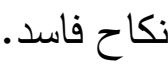

•. موطن الاتفاق: اتفقت الدذاهب الفقهية الأربعة على أن من شروط الإحصان

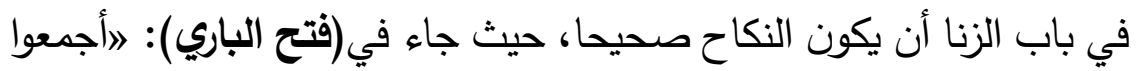
على أنه لا يكون الإحصان بالنكاح الفاسد ولا الثبهةها (1).

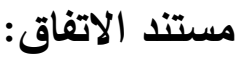
يستتد هذا الاتفاق إلى أدلة، منها:

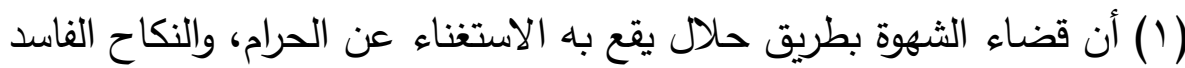

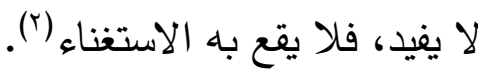

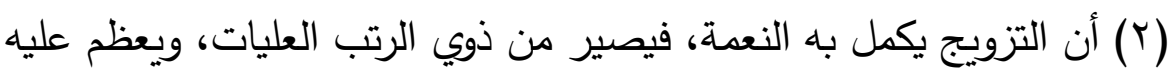

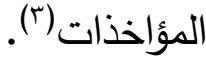
الثرط السادس: أن يحصل الوطء في القبل، فلا يحصل الإحصان في نكاح

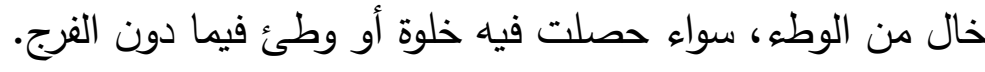

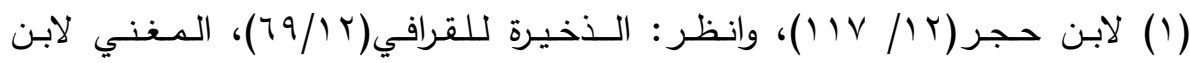

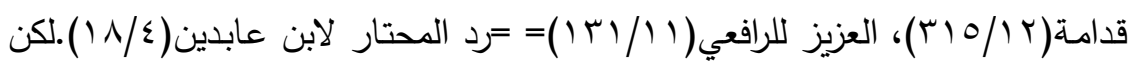

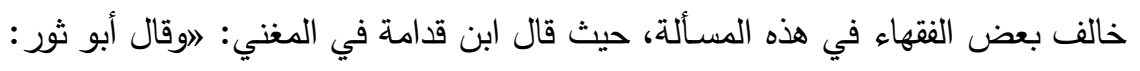

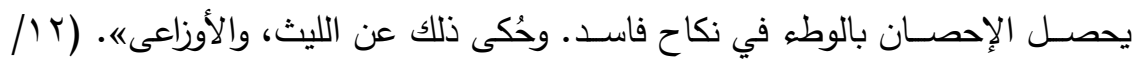

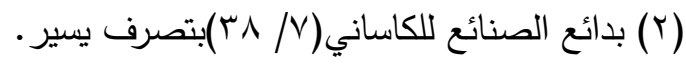
(ץ) الذخيرة للقرافي(r / / 79)بتصرف يسير. 
•. موطن الإجماع: أجمع العلماء على أن من شروط الإحصان في باب الزنا

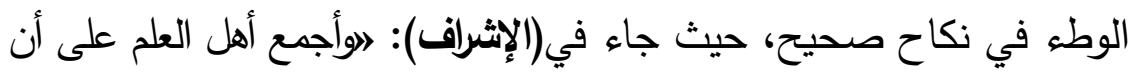
الهرو لا يكون بعقد النكاح محصناً، حتى يكون معه الوطوهـ (1). • مستند الإجماع: يستتد هذا الإجماع إلى أدلة، منها:

(1) عن عبادة بن الصامت، قال: قال رسول الله صلى الله عليه وسلم: اخذوا عني، خذوا عني، قد جعل الله لهن سبيلا، البكر بالبكر جلد مائة ونفي سنة،

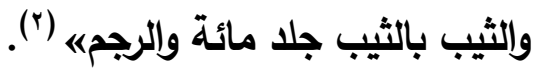
وجه الدلالة: أن النبي صلى الله عليه وسلم قال: االثيب بالثيب جلد

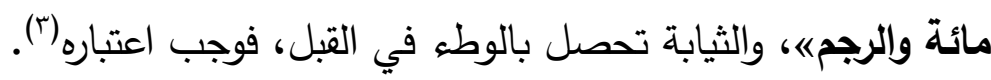

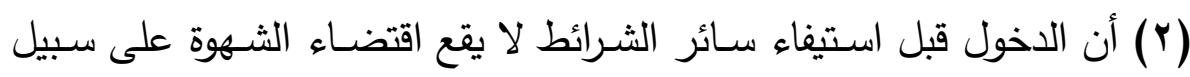

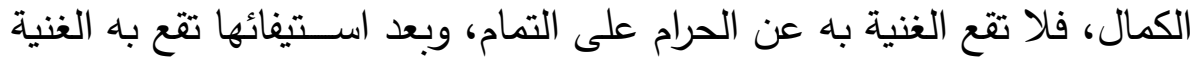

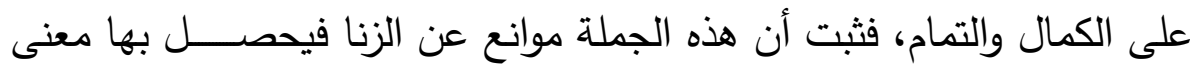
الإحصان وهو الدخول في الحصن عن الزنالئ.

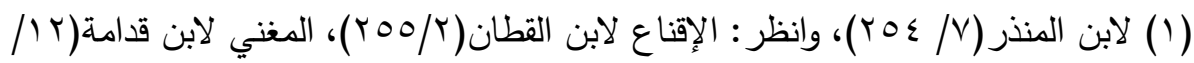
.

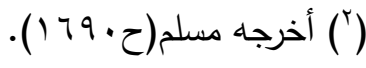

$$
\begin{aligned}
& \text { (r) المغني لابن قدامة(r/ / / / (T). }
\end{aligned}
$$

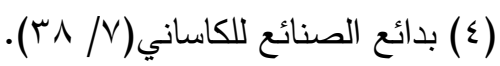




\section{الاطلب الثاني \\ شروط الإمصان المثتلف فيها في باب هد الزنا.

$$
\text { • أثرط الأول: إسلام الزوجين. }
$$

اختلف الفقهاء في اشتراط الإسلام لحصول الإحصان على قولين:

القول الأول: يثترط الإسلام لحصول الإحصان. وهو مذهب الحنفية(1)،

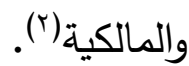

القول الثاني: لا يشترط الإسلام لحصول الإحصان. وهو مذهب

الثافعية(ץ)، والحنابلة (؛).

• \$ أدلة الفقهاء:

أولًا: من أدلة القول باشتراط الإسلام لحصول الإحصان:

[1] عن ابن عمر رضي الله عنها، عن النبي صلى الله عليه وسلم قال: الهن أثرك باله

فليس بمحنه|(*).

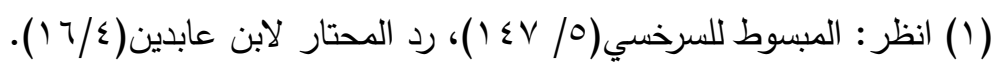

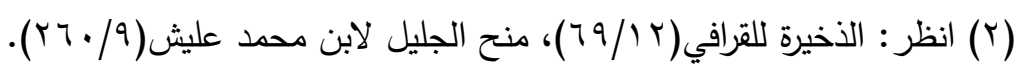

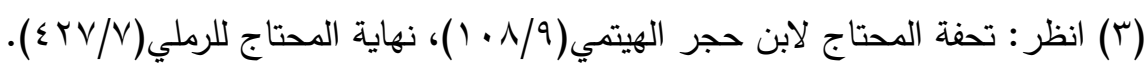

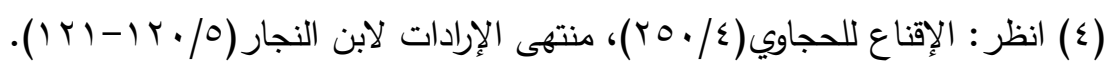

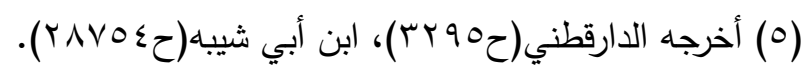

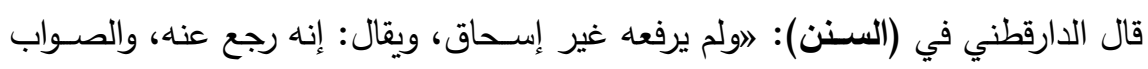

$$
\begin{aligned}
& \text { موقوف《. (lVA/s). }
\end{aligned}
$$




\section{ونوقش: بأن الحديث لم يثبت(') - (1)}

الله

ويمكن أن يجاب عنه: بأن الحديث موقوف على ابن عمر رضــــي

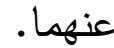

ورد عليه: بأنه يتعين حمله على إحصان القذف، جمعا بينه وبين حديث

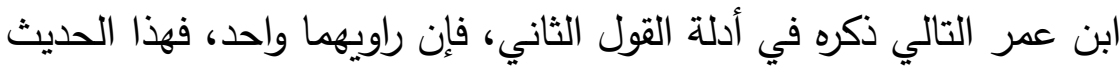

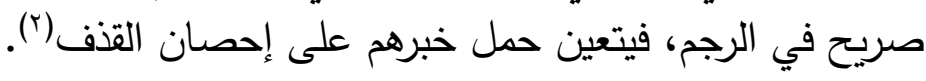

[؟r عن كعب بن مالك، أنه أراد أن يتزوج يهودية أو نصــرانية، فـــأل النبي

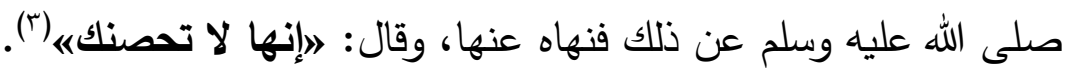

ونوقش: بأن الحديث لم يثبت (ء).

[ץ] أنه إحصان من شرطه الحرية، فكان الإسلام شرطا فيه، كإحصان القذف،

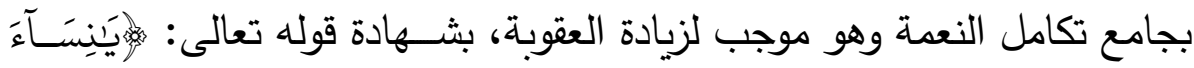

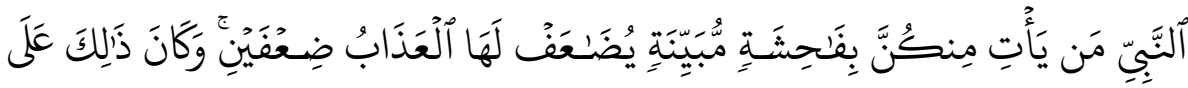

(1) انظر : تنقيح التحقيق لابن عبدالهادي(؟/7 (0)).

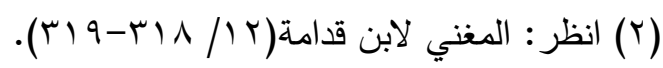

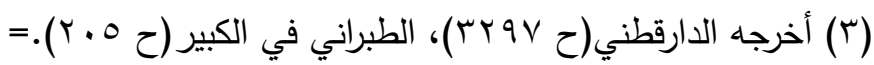

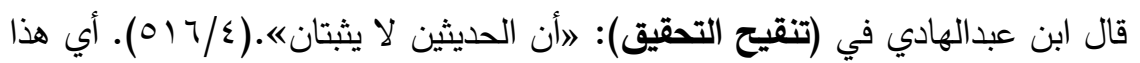

الحديث والحديث الأول الدكور في أدلة هذا القول.

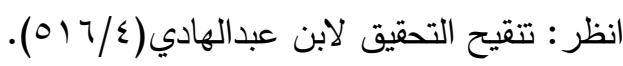




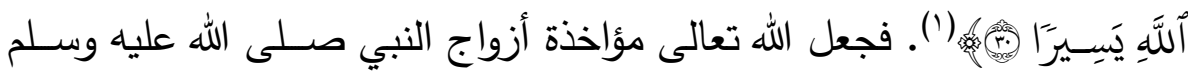

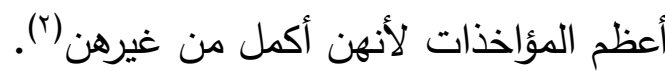

ونوقش: بأنه لا يصح القياس على إحصان القذف؛ لأن من شرطه العفة،

$$
\text { وليست شرطا هنا"). }
$$

[؛ [ أن الإحصــان فضــيلة، ولا فضـيلة مع عم الإنــام، وهذا مبناه على أن الوطء في نكاح

$$
\text { صحيح هو منلوب إليها(). }
$$

$$
\text { [0] أن النبي ؛ }
$$

ونوقش: بأنه دليل بعيد، بل رجمهما بحكم الله الذي لا حكم سواه(؟).

ثانيًا: من أدلة القول بعدم اشتراط الإسلام لحصول الإحصان:

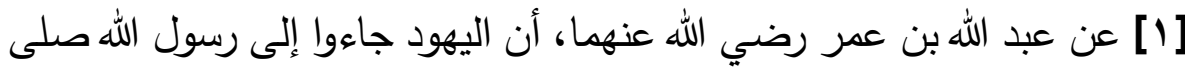

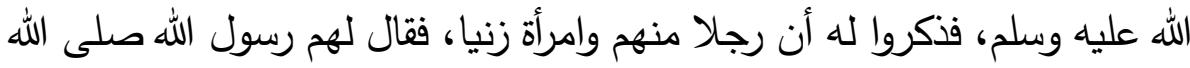

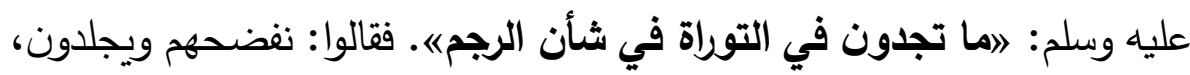

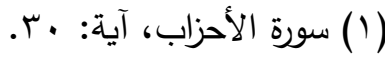

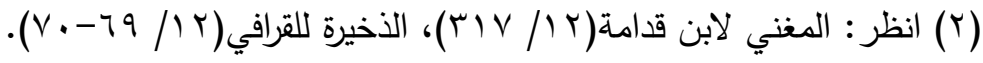

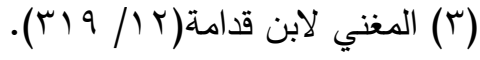

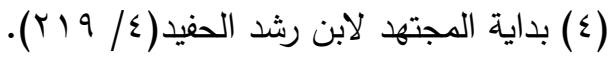

$$
\begin{aligned}
& \text { (0) انظر : زاد المعاد لابن القيم(0/ r r (T). } \\
& \text { (؟) انظر : زاد المعاد لابن القيم(0/ س r؟). } \\
& -1910-
\end{aligned}
$$


فقال عبد الله بن سلام: كذبتم إن فيها الرجم فأتوا بالتوراة، فنشروها، فوضع أحدهم فله

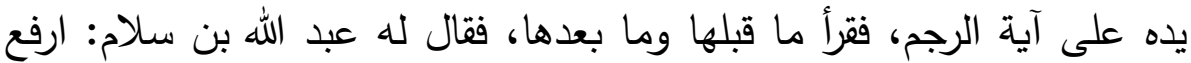

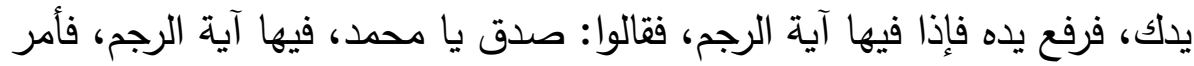

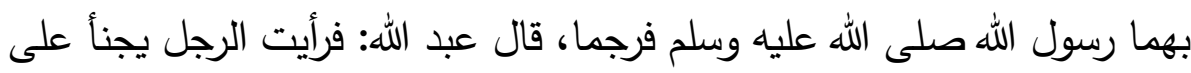

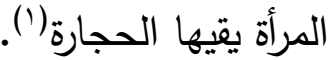
وجه الدلالة: أن الحديث يدل على أن الإسلام ليس بشرط في الإحصان،

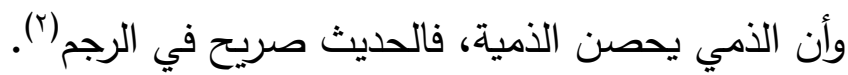

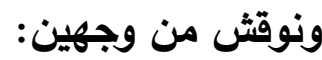

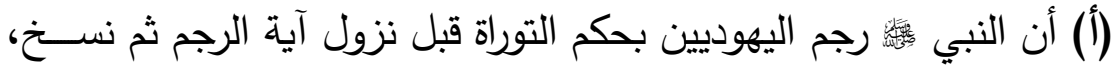
بدليل أنه راجعها، فلما تبين له أن ذلك حكم الله عليهم، أقامه فيهم، وفيها أنزئ أنزل

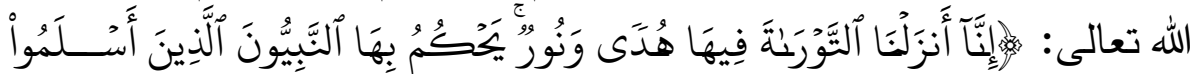

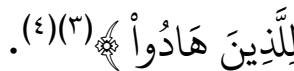

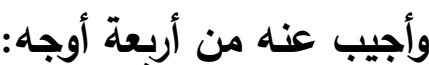

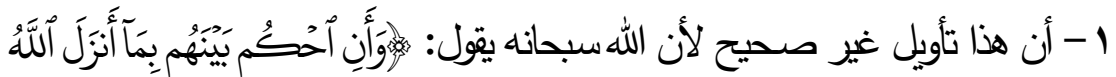

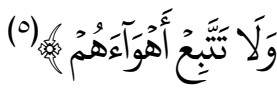

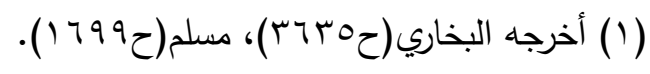

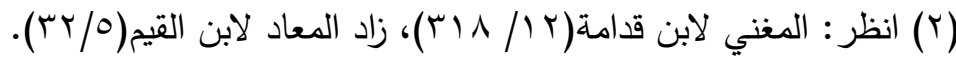

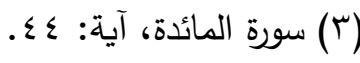

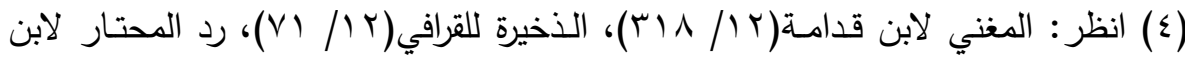
عابدين(\&/ (17) (17).

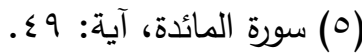


وإنما جاءه القوم مسـتفتين طمعا في أن يرخص لهم في ترك الرجم ليعطلوا به حكم التوراة، فأشار عليهخ

رسول الله ولم ما كتموه من حكم التوراة ثم حكم عليهم بحكم الإسلام على شرائطه

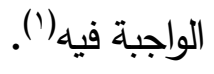

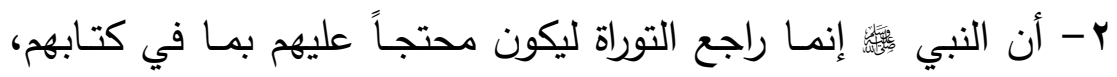

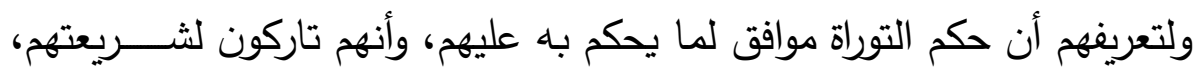

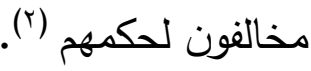

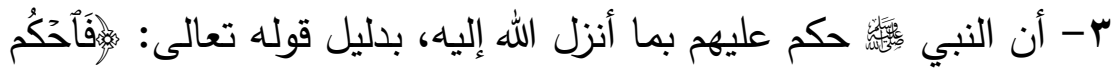

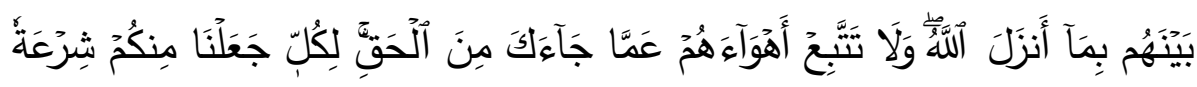

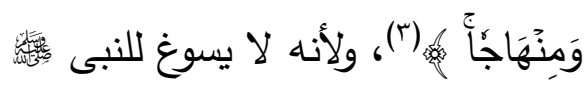
الحكم بغير شـــريعته()، لذا إذا تحاكم إلينا أهل الذمة فلا نحكم بينهم إلا

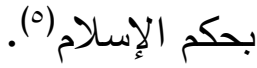

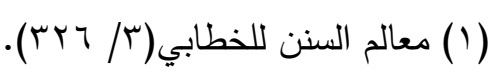

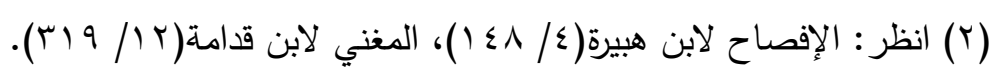

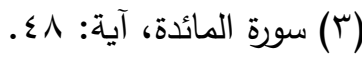

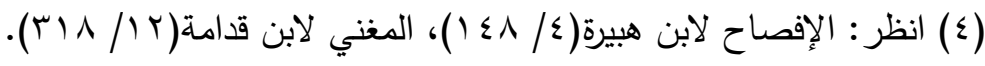

$$
\begin{aligned}
& \text { (0) انظر : زاد المعاد لابن القيم(0/ r بr). }
\end{aligned}
$$


ـ - أن النبي صلى الله عليه وسلم حكم بينهم بالحق المحض، فيجب

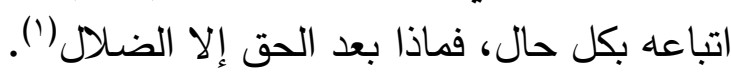

(ب) أن اليهود لم يكونوا أهل ذمة عندما جاؤوا إلى النبي إنما كما في هذا

الحديث (r) (ب) (ب)

وأجيب عنه: بأنهم أهل ذمة، ولا شك أن هذا كان بعد العهذ الذي وقع بين النبي صلى الله عليه وسلم وبينهم، ولم يكونوا إذ ذالك حربا، كيف وقد تحاكموا

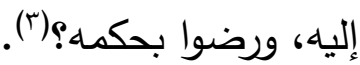

[ץ] عن عبادة بن الصامت، قال: قال رسول الله صلى الله عليه وسلم: "خذوا عني، خذوا عني، قد جعل الله لهن سبيلا، البكر بالبكر جلد مئة ونفي سنة،

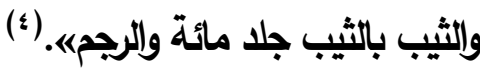

وجه الدلالة: جاء في (المنهاج شرح صحيح مسلم): اوأجمع العلماء

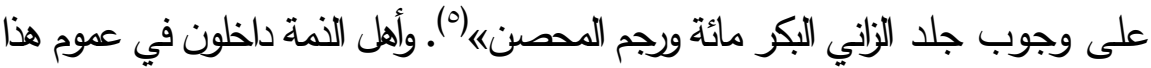
الحيث بلكليل حليث ابن عمر السابق(").

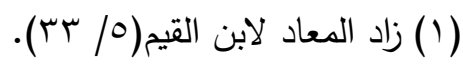

(r) انظر : زاد المعاد لابن القيم(0/ / r (T).

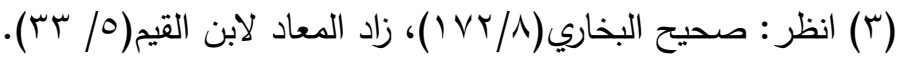

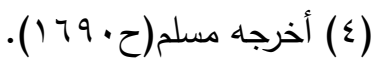

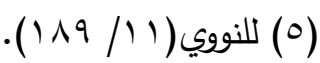

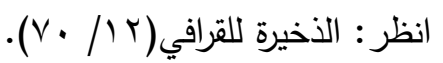


[ب] أن الجناية بالزنا اسـتوت من المســم والذمي، فيجب أن يسـتويا في

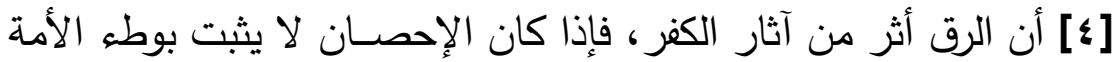

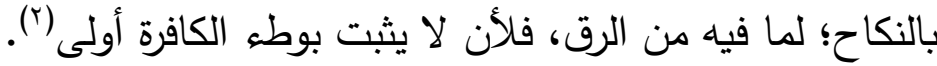

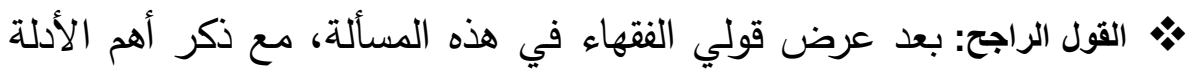

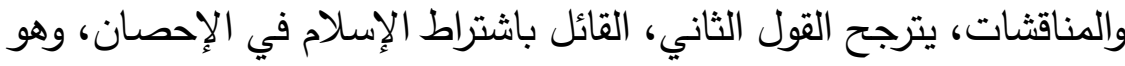

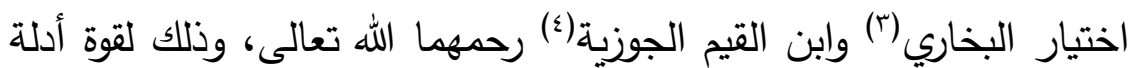
هذا القول، ومناقثة أدلة القول الأول، ولوجود النص الصحيح من السنة، الدال على عم اشتراط الإنسلام لحصول الإحصان. والله أعلم. الثــرط الثاني: الكمال في النكاح حال الوطء، فيطأ الرجل البالغ العاقل الحر امرأة بالغة عاقلة حرة.

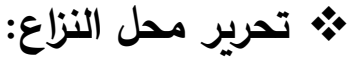

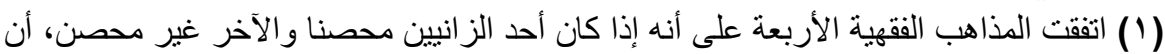

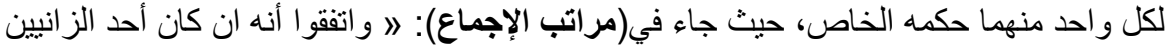

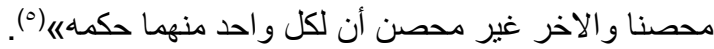

(ץ) واختلف الفقهاء في حكم اشتراط الكمال في الرجل والمرأة حال الوطء في

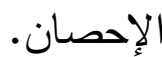

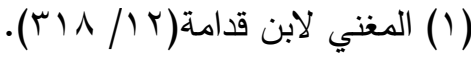

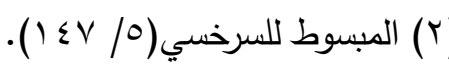

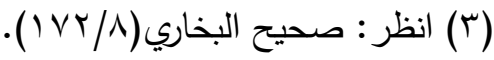

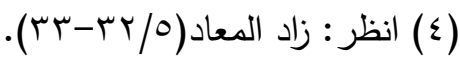

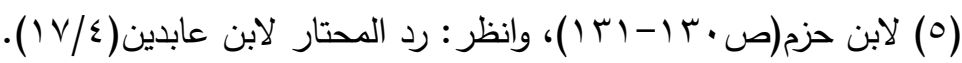


اختلف الفقهاء في اشتراط الكمال في الرجل والمرأة حال الوطء، على قولين: القول الأول: يشترط وجود الكمال في النكاح حال الوطء. وهو مذهب الحنفية(') والحنابلة(')

القول الثاني: لا يشترط وجود الكمال في النكاح حال الوطء، فإنه إذا كان أحدها كاملا والآخر ناقص، حصل الإحصان للكامل. وهو مذهب

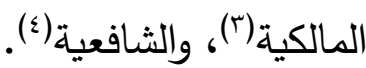
•. أدلة الفقهاء: أولًا: من أدلة القول باشتراط وجود الكمال في النكاح حال الوطء : [1 ] عن كعب بن مالك رضـي الله عنه، أنه أراد أن يتزوج يهودية أو نصـرانية،

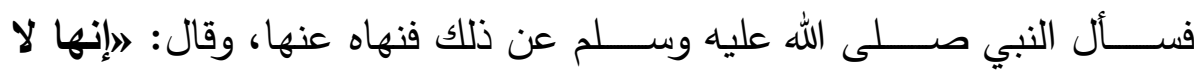
تحصنك «.)

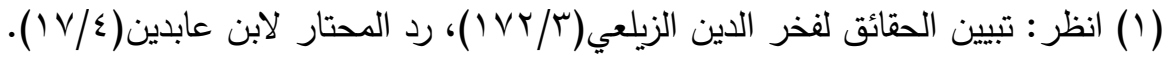

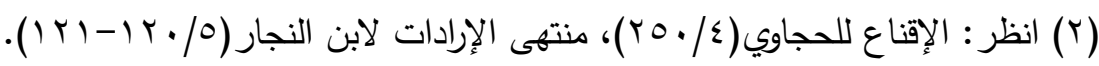

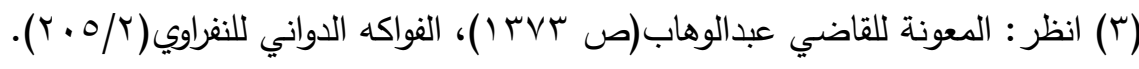

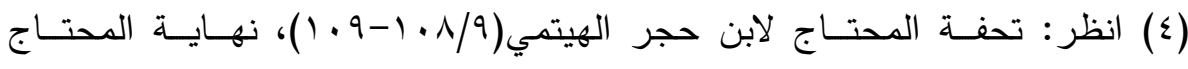

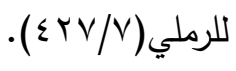

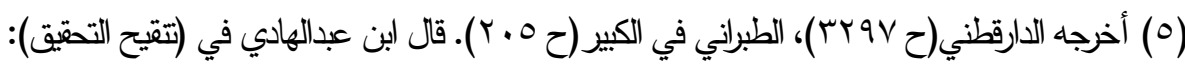

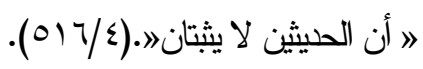

$$
\begin{aligned}
& -194 \cdot-
\end{aligned}
$$


وجه الالالة: أن اقتضـاء الثـهوة بالكافرة قاصـر ؛ لأن طبع المســـم ينفر عن

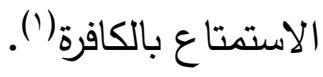
[?] [ن ابن عمر رضي الله عنهما، عن النبي صلى الله عليه وسلم قال: الامن أثرك باله فليس بمحصنه (r). ونوقش الحديثان: بأنهما لم يثبتا(「).

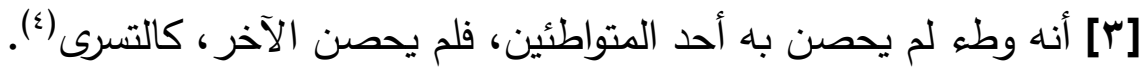
ويمكن أن يناقش: بوجود الفرق بين النكاح والتسري.

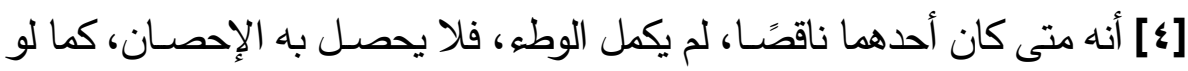

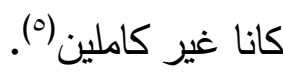

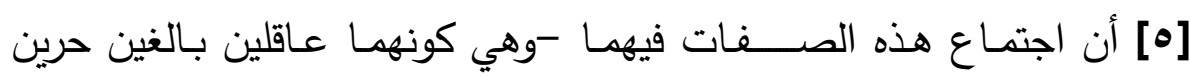

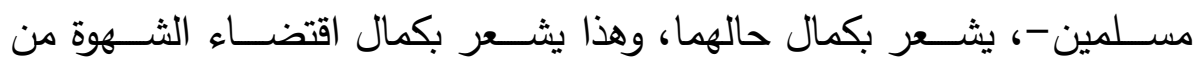

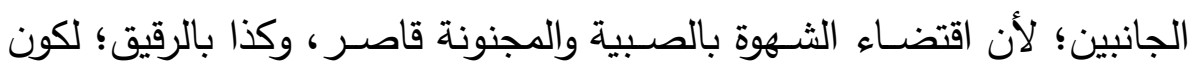

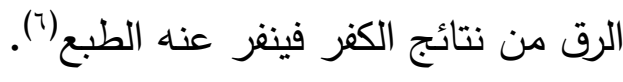

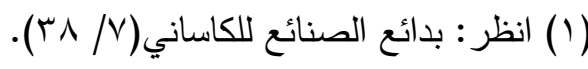

$$
\begin{aligned}
& \text { (Y) تقدم تخريجه(ص r ( ). }
\end{aligned}
$$

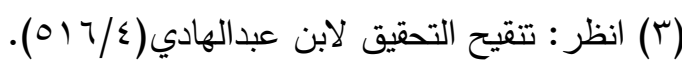

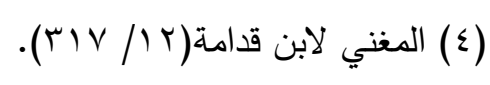

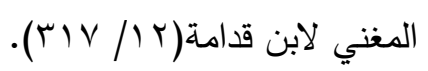

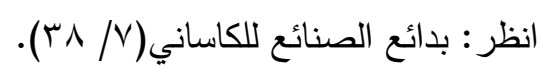


[?] أن هذه الصـــفات من أعظم النعم، وكلها زواجر عن الزنا، والجناية عند

توفر النعمة ووجود المانع أغلظ وأقبح، فيناط بها نهاية العقوبة (1) أن الطبع ينفر عن صحبة المجنونة، وقلما يرغب في الصغيرة لقلة رغبتها

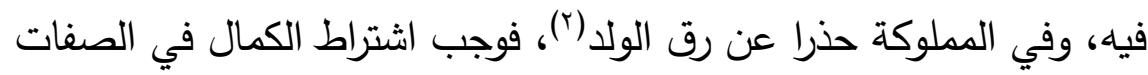

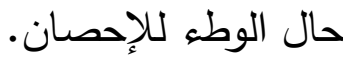
ثانيًا: من أدلة القول بعدم اشتراط وجود الكمال في النكاح حال الوطء:

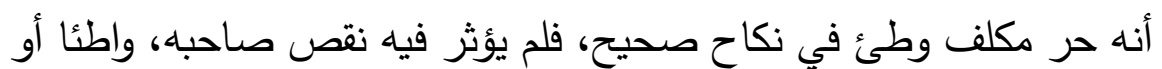

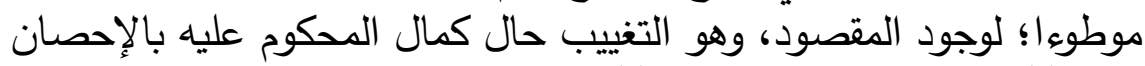

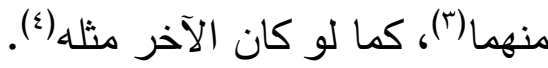

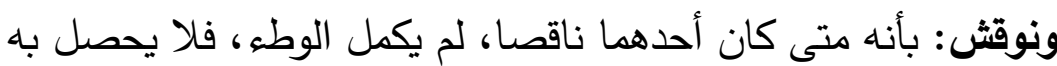

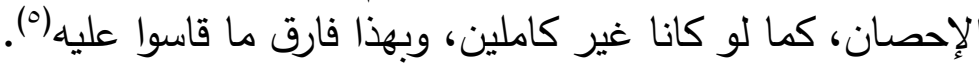

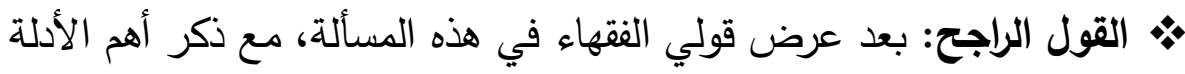

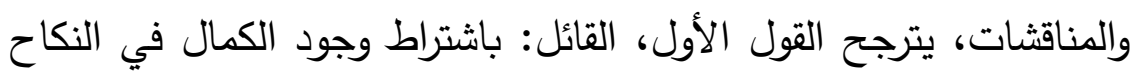

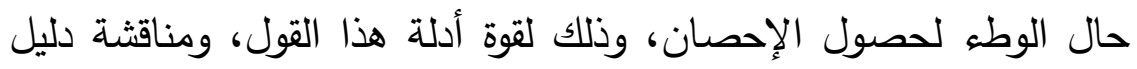

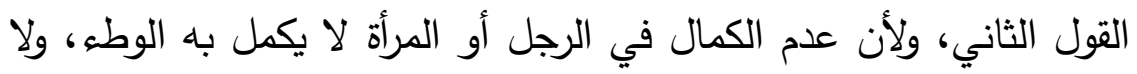
تحصل معه النعمة، الداعية لإحصانه. والله أعلم.

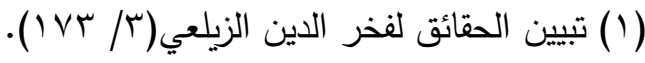

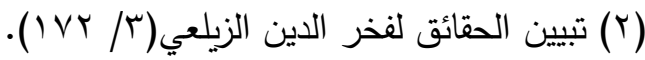

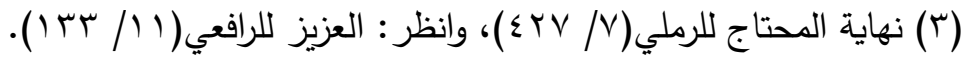

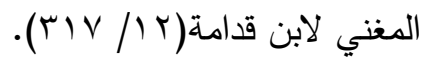

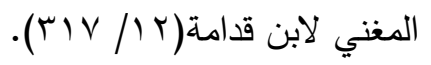




\section{البمث الثالث}

\section{شـوط الإمصان في باب مد القفف.}

شــرع الله تعالى حد القذف، حفظًا للأعراض مما يثــينها، حيث جاء في

(المفني): (أجمع العلماء على وجوب الدد على من قذف الدحصــن، إذا كان

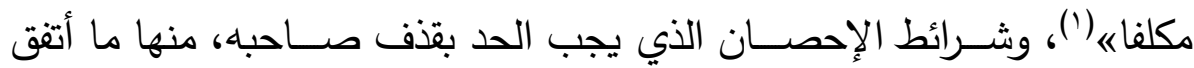
على اشتراطه العلماء، ومنها ما اختلفوا فيه، كما سيتم بيانه في هذا المبحث.

\section{الإلبا الأول}

\section{شروط الإصمان المتفق مليها في باب صد القذف.}

الثرط الأول: أن يكون عاقلا، فلا يحصل الإحصان من مجنون.

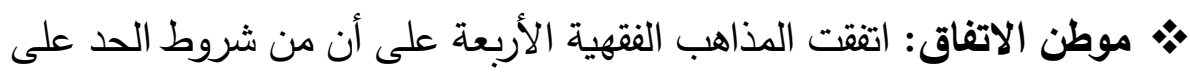

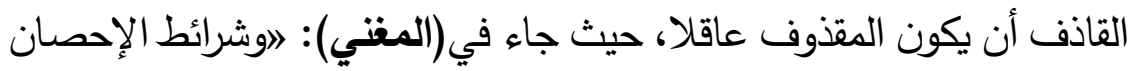
الذي يجب الحد بقذف صاحبه خمسة: العقل، والحرية، والإنلام، والعفة عن

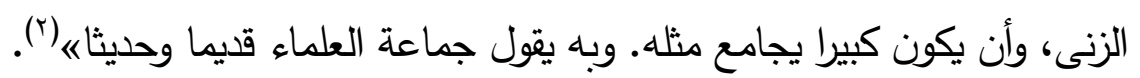

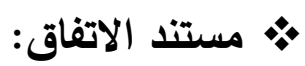
يستند هذا الاتفاق إلى أدلة، منها:

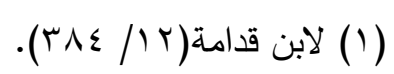

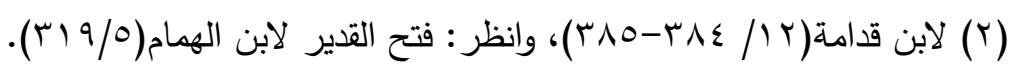




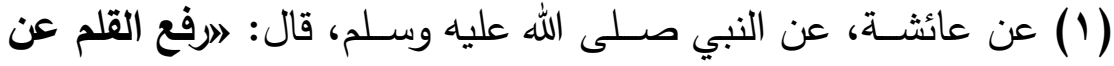
ثلاث: عن النائم حتى يستيقظ، وعن الصغير حتى يكبر ، وعن المجنون حتى

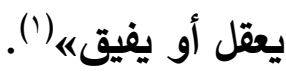

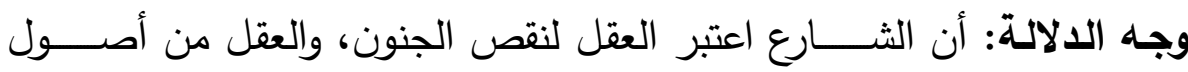

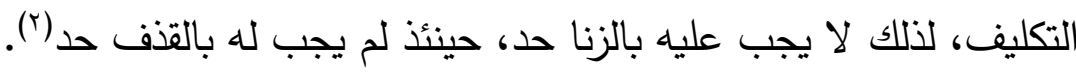
(r) أن العار لا يلحق بالمجنون لعدم تحقق فعل الزنا منه(r). (ץ) أن حد القذف المراد منه دفع المعرة عن المقذوف، ولا معرة على من عدم العقل إذ لا يوصف الوطء فيه ولا منه بأنه زنا (؛). الثرط الثاني: أن يكون مسلما.

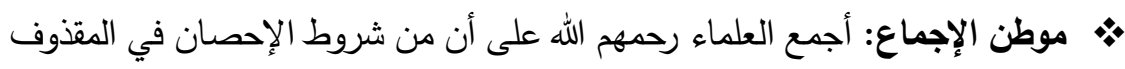

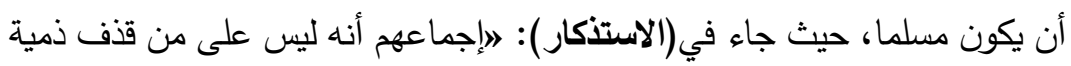

$$
\text { * مستند الإجماع: أو مملوكة حسا، }
$$

يستند هذا الإجماع إلى أدلة، منها:

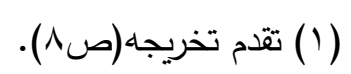

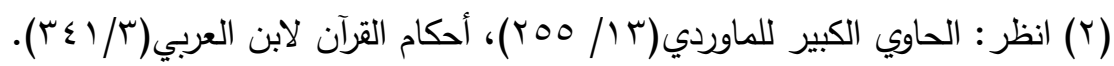

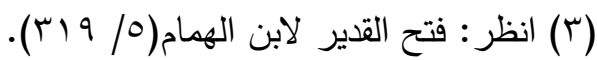

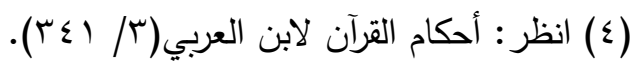

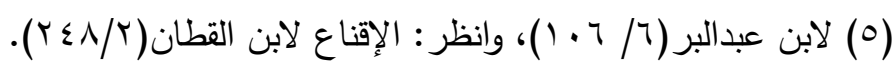




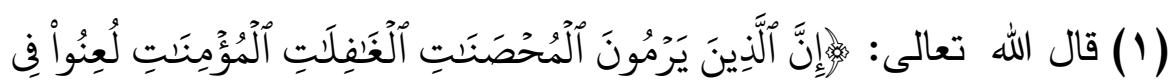

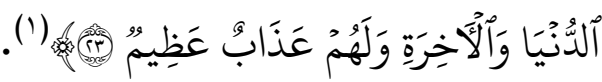
وجه الدلالة: دلت الآية على أن الإيمان شــرط في الإحصــــان في باب

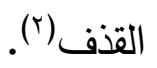

(Y) عن ابن عمر رضي الله عنهما قال: اهن أشرك باله فليس بمحصنه(r). وجه الدلالة: أن الحديث نفى الإحصان عن المشرك، فلل على أن الإسلام من

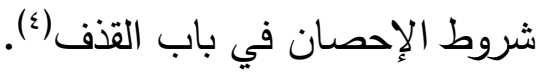

(T) أنه لما لم يأخذ نفس المسلم بنفس الكافر لم يؤخذ عرضها بعرضها(0). (؛) أن الحد إنما وجب بالقفف دفعا لعار الزنا عن المقذوف، وما في الكافر من عار الكفر أعظم(ان). الثرط الثالث: أن يكون المقذوف حرا، فلا يكون الإحصان من مملوك.

$$
\begin{aligned}
& \text { (1) سورة النور، آية: بr. }
\end{aligned}
$$

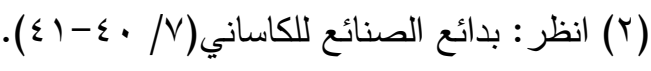

$$
\begin{aligned}
& \text { (r) تقدم تخريجاء(ص r ا ). }
\end{aligned}
$$

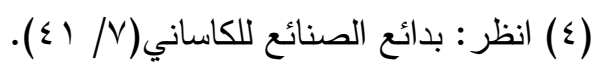

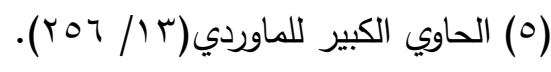

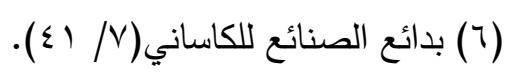


• موطن الإجماع: أجمع العلماء رحمهم الله تعالى على أنه لا حد على من

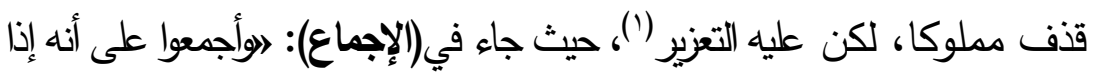

$$
\begin{aligned}
& \text { افترى أحد على عبد، فلا حد عليهه (r). } \\
& \text { • • مستتد الإجماع: }
\end{aligned}
$$

يستند هذا الإجماع إلى أدلة، منها:

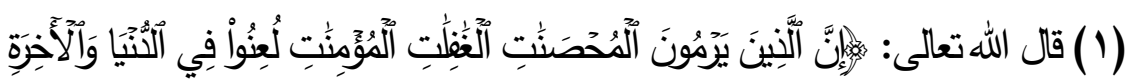

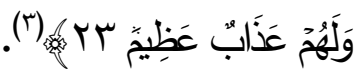

وجه الدلائة: دلت هذه الآية على أن المراد من المحصــــات في هذه الآية

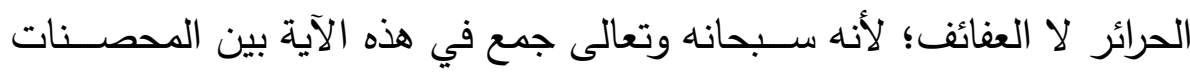

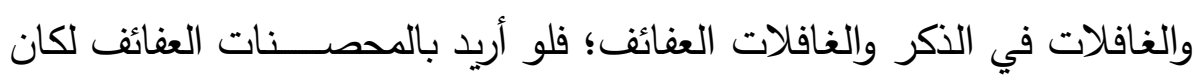
تكرارا()، فل ذلك على اشتراط الحرية للمقذوف في الإحصان.

(r) عن أبي هريرة رضي الله عنه، قال: سمعت أبا القاسم صلى الله عليه وسلم

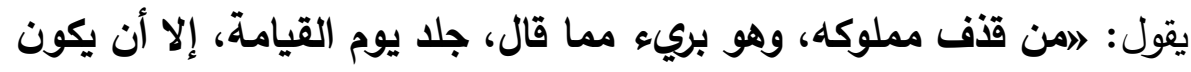

كما قاله|(o).

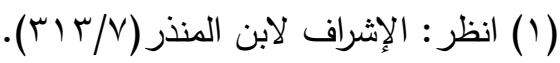

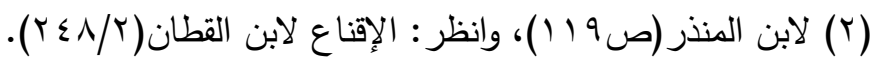

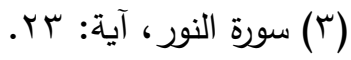

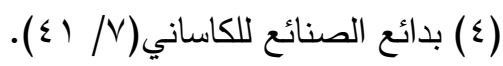

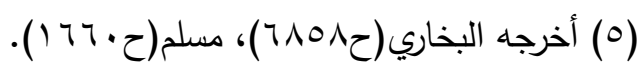

$$
\begin{aligned}
& -1947-
\end{aligned}
$$


وجه الدلالة: جاء في(المنهاج): (هفيه إثــــارة إلى أنه لا حد على قاذف العبد

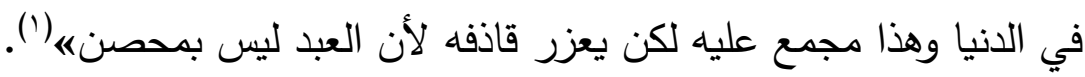
(r) أن الزنا أغلظ من القذف، فلما منعه نقص الرق من كمال حد الزنا، كان أولى أن يمنع الحد على من قذفه بالزنا (؟).

( ) أنه لما منعه نقص الرق أن تؤخذ بنفسه نفس حر، كان أولى أن يمنع أن يؤخذ

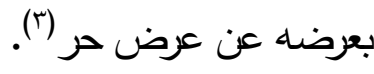
الثرط الرابع: العفة عن الزنا. •• موطن الاتفاق: اتفقت المذاهب الفقهية الأربعة على اشتراط العفة عن الفواحش في المقذوف لحصول الإحصان لله، حيث جاء في(المغني): الوشرائط الإحصان الذي يجب الحد بقذف صاحبه خمسة؛ العقل، والحرية، والإسلام، والعفة عن الزنى، وأن يكون كبيرا يجامع مثله. وبه يقول جماعة لإحة العلماء قديما وحديثاء (๕).

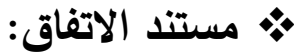
يستند هذا الاتفاق إلى أدلة، منها:

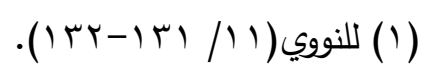$$
\text { (r) انظر : الحاوي الكبير للماوردي(r / / (ro0). }
$$$$
\text { (r) انظر : الحاوي الكبير للماوردي(r / / (r00). }
$$

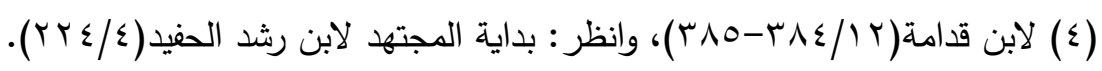




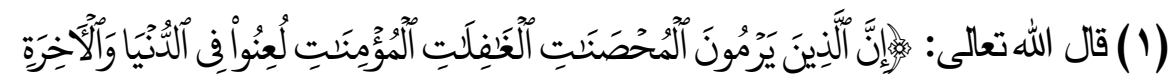

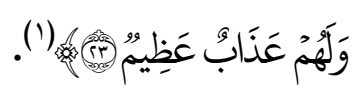

وجه الدلالة: أن المراد بالآيـة أن الذين يرمون المحصـــات أي العنيفات،

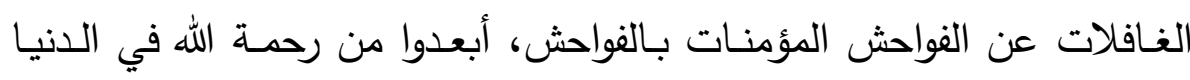

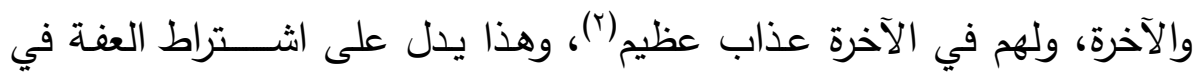

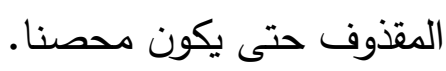

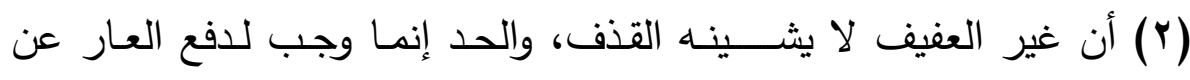
الكقذوف، ومن لا عفة له عن الزنا لا يلحقه العار بالقذف بالزناب(r).

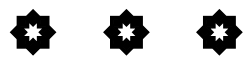

$$
\begin{aligned}
& \text { (1) - (1) سورة النور، آية: سץ. }
\end{aligned}
$$

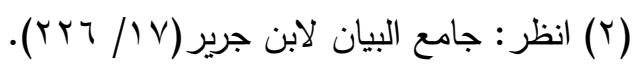

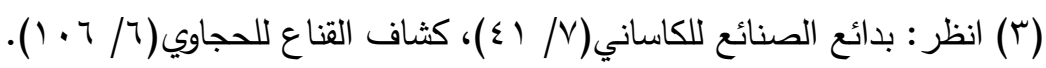

$$
\begin{aligned}
& -19 Y \wedge-
\end{aligned}
$$




\section{الإلب الثاني \\ شروط الإصمان المفتلف فيها في باب هد القذف.}

$$
\begin{aligned}
& \text { الشرط الأول: بلوغ المقذوف. } \\
& \text { • أقوال الفقهاء: }
\end{aligned}
$$

اختلف الفقهاء في اشتراط بلوغ المقذوف لحصول الإحصان على قولين:

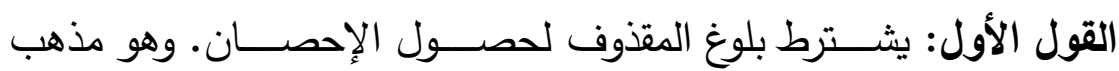

الجمهور من الحنفية(')، والمالكية(")، والثافعية(")

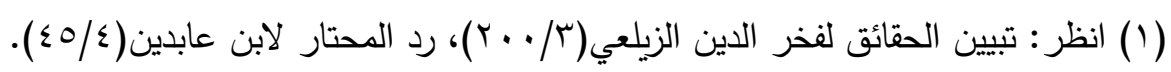

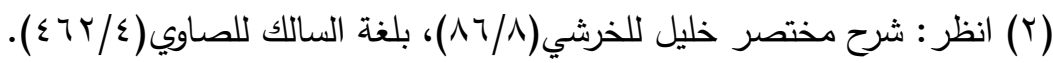

لكن إن كان القذف بنفي النسب اشترط في المقذوف الحرية، والإسلام فقط، ويزاد عليهما

في القذف بزنا أربعة: البلوغ، والعقل، والعفة والآلة. انظر : نفس الصدرين.

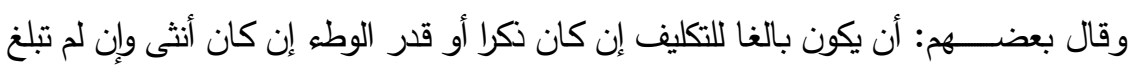

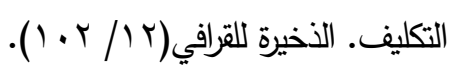

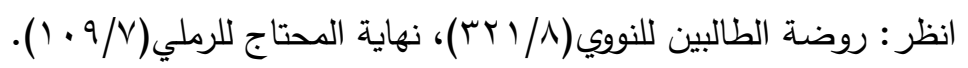


القول الثاني: لا يشترط بلوغ المقذوف لحصـول الإحصـان، بل أن يكون

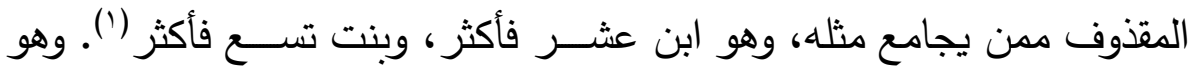

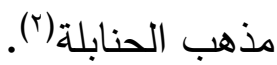

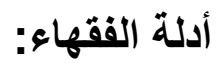
أولًا: من أدلة القول باشتراط بلوغ المقذوف لحصول الإحصان: [1] عن عائثــة رضـي الله عنها، عن النبي صـلى الله عليه وســلم، قال:

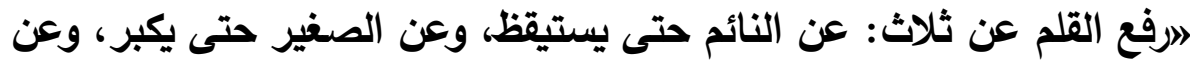

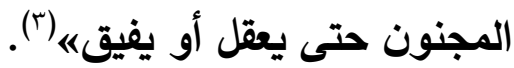

وجه الدلالة: أن البلوغ أصـل في التكليف، والتكليف سـاقط عن الصـغير ، لذا لا

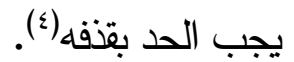

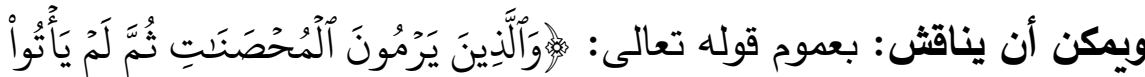

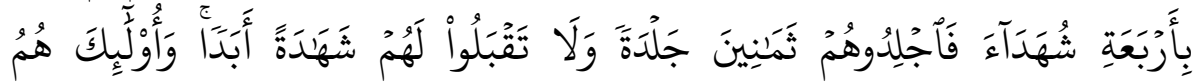

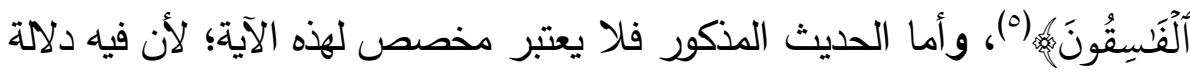

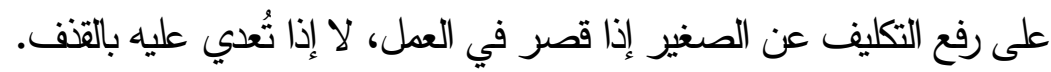

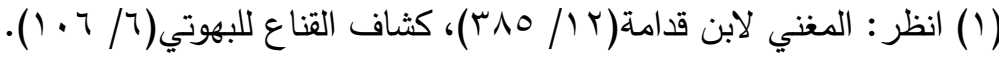

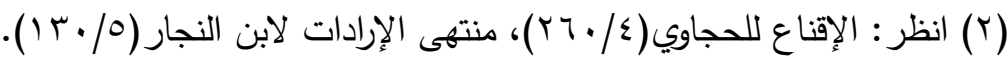

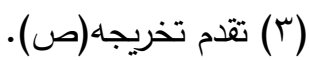

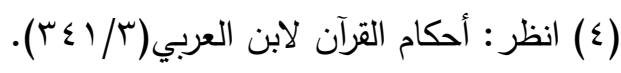

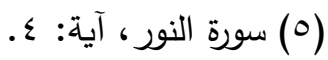


[ץ] قياس شرط البلوغ على شرط العقل، بجامع أن كلا منهما لا تكليف عليه، والمجنون اتفق العلماء على عدم إحصانه(')

ويمكن أن يناقش: بوجود الفرق بين الصغير والمجنون، حيث أن الصغير تصح منه بعض العبادات دون المجنون.

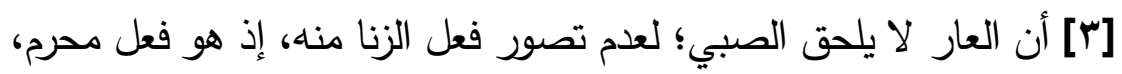

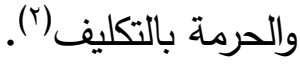

ويمكن أن يناقش: بعدم التسليم لذلك، بل يلحق الصبي والجارية العار إذا

قُذفوا بالزنا؛ لوجود العقل والحرية فيهما.

لا يوجب حدا، فلا يجب الحد بالقذف به، كزنى لئى

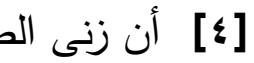

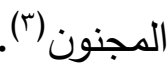

ويمكن أن يناقش: بأنه لا يلزم من عدم إقامة الحد عليه - إذا زنا لعلم بلوغه -،

عم إحصانه عند القنف.

ثانيًا: من أدلة القول بعدم اشتراط بلوغ المقذوف لحصول الإحصان:

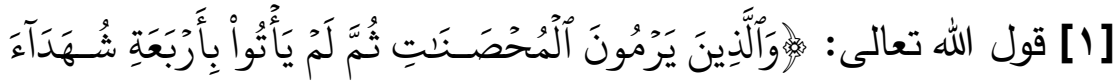

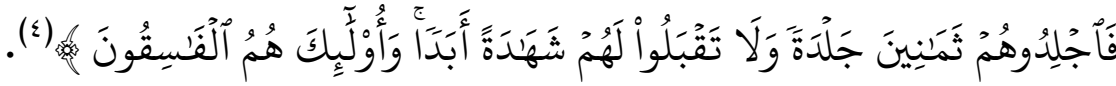

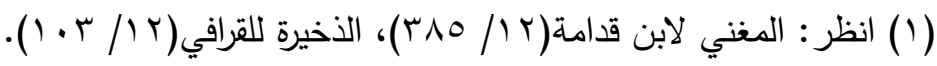

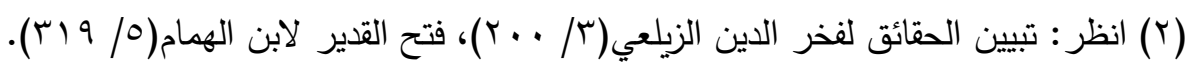

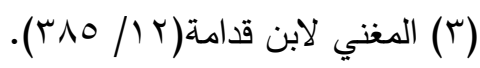

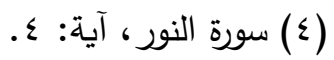


وجه الدلالة: أن الإحصان في لغة العرب: هو المنع، والصغار : محصنون بمنع الله تعالى لهم من الزنى، وبمنع أهليهه، فإذا كان الصـغير داخلا في قوله:

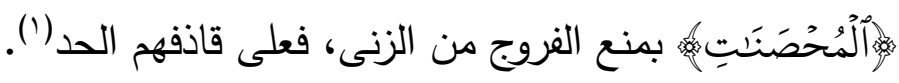

[ץ] أن الصـير يلحقه الثـين والعار بإضــافة الزنا إليه، ولهذا جعل عيبًا

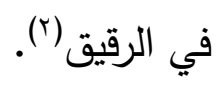

[־] أنه الصـــير حر عاقل عفيف يتعير بهذا القول الممكن صــدقه،

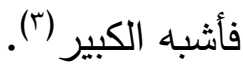

• • القول الراجح: بعد عرض قولي الفقهاء في هذه المسألة، مع ذكر أهم الأدلة

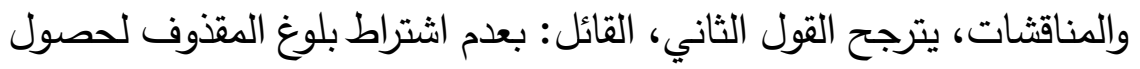
الإحصان، وذلك لقوة أدلة هذا القول، ومناقثة أدلة القول الأول، ولأن ما

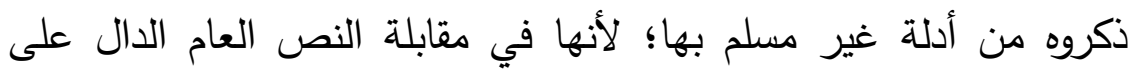
إحصان الصغير ؛ لمنع نفسه وأهله له من الزنا، واتصاف الصغير لهير والجارية بالعقل والحرية مما يسبب لحوق العار لهما. والله أعلم. الثرط الثاني: وجود آلة الزنا في المقذوف.

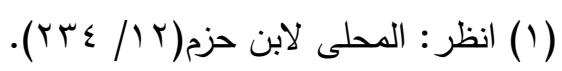

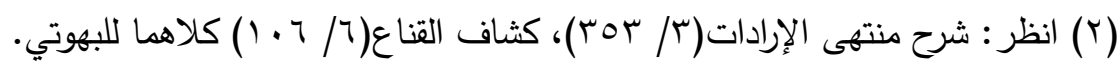

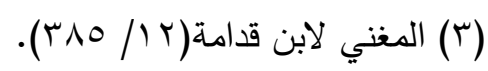


اختلف الفقهاء في اثتراطوجود آلة الزنا في المقنوف لإحصانه، كالمجبوب(')

$$
\text { والرثقاء (ץ)، على قولين: }
$$

القول الأول: يشترط وجود آلة الزنا في المقذوف لإحصانه، فمن لم يكن

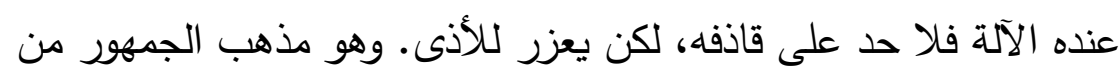

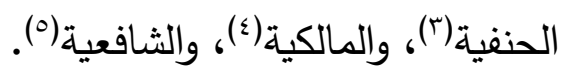
القول الثاني: لا يشترط وجود آلة الزنا في المقذوف لإحصانه. وهو مذهب الحنابلة) (؟).

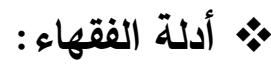

أولًا: من أدلة القول باشتراط وجود آلة الزنا في المقذوف لإحصانه:

(1) المجبوب، هو: مقطوع الذكر والأنثين جميعا أو مقطوع الذكر وحده. انظر : رد المحتار

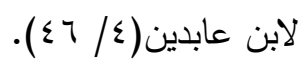

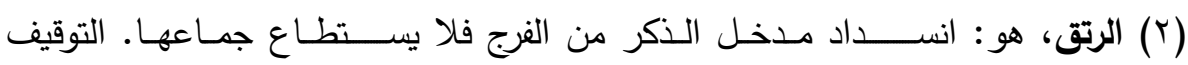

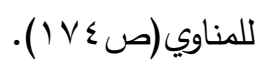

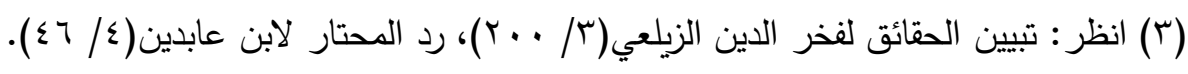

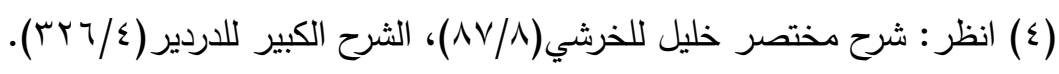

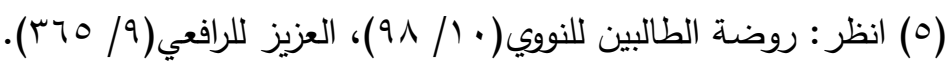

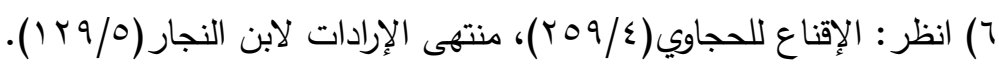




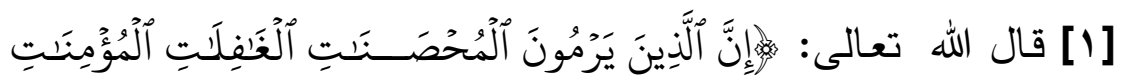

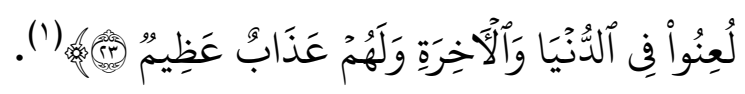

وجه الدلالة: الغافلات العفائف عن الزنا(؟)، والمجبوب والرتقاء لا يمكنه الزنا،

$$
\text { فلم يلحقه العار ("). }
$$

ويمكن أن يناقش: بأن المجبوب والرتقاء يلحقهم العار كما يلحق الســليم،

$$
\text { ولا يوجد دليل على تخصيصهما من هذا النص. }
$$

[؟] أنهم رموا من لا يمكنه الجماع، فلم يلحقه عار بالقذف، لظهور كذب

$$
\text { ويمكن أن يناقش: بمثل ما نوقش به دليلهم الأول. }
$$

ثانيًا: من أدلة القول بعدم اشتراط وجود آلة الزنا في المقذوف لإحصانه:

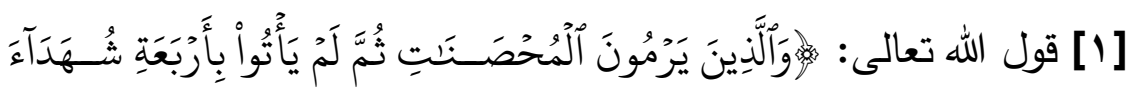

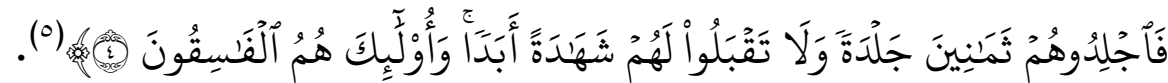

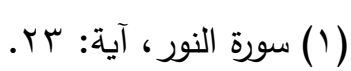

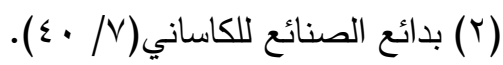

$$
\begin{aligned}
& \text { (ץ) انظر : رد المحتار لابن عابدين(§ / ؟؟). }
\end{aligned}
$$

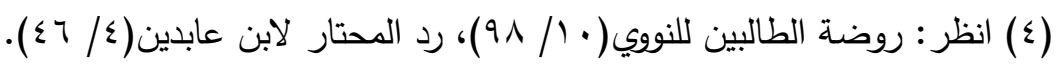

$$
\begin{aligned}
& \text { (0) سورة النور ، آية: ع. }
\end{aligned}
$$


وجها الدلالة: عموم الآيةل(')، حيث أن الإحصـــــان في لغة العرب: هو

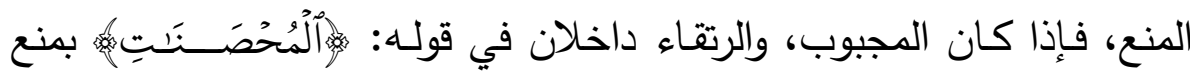
الفروج من الزنى، فعلى قاذفهم الحد (؟).

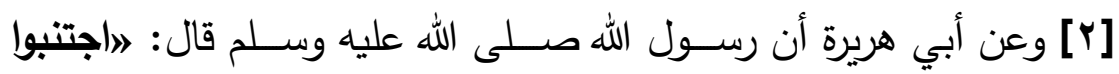

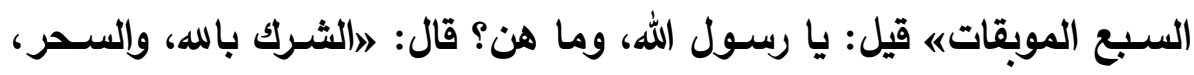

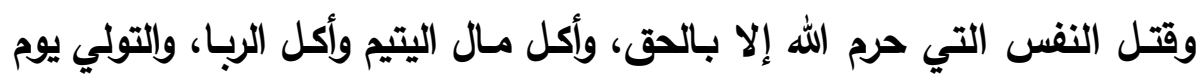

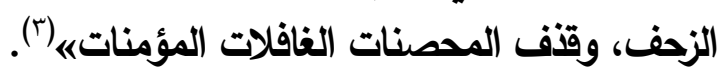

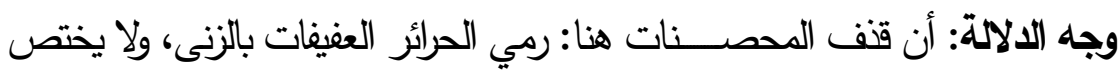
بالمزوجات، بل حكم

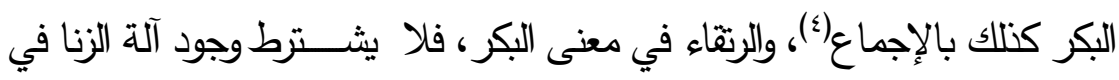
المقنوف لإحصانه. •. القول الراجح: بعد عرض قولي الفقهاء في هذه المسألة، مع ذكر أهم الأدلة

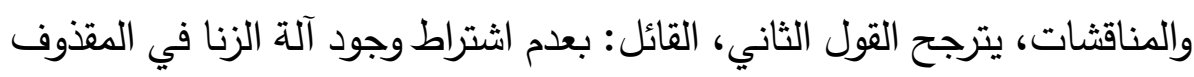

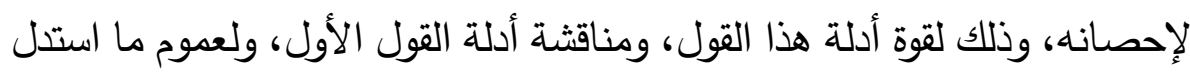

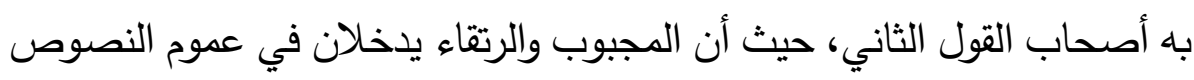

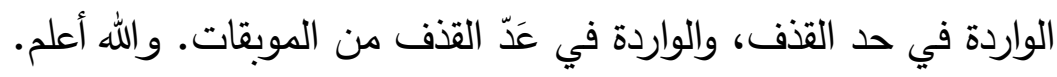

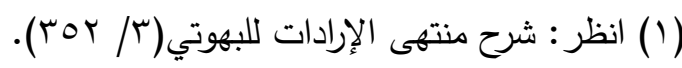

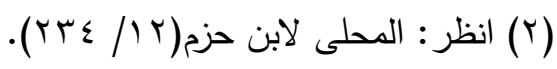

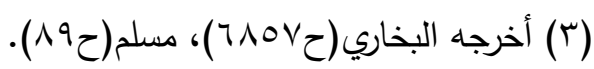

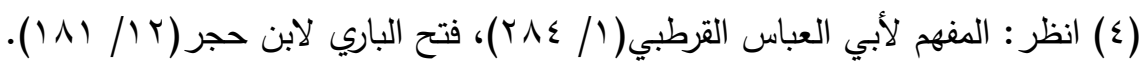




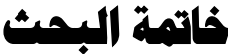

أحمد الله تبارك وتعالى أن يسر لي طريق العلم، وهيأ لي أسبابه، ومن ذلك هذا البحث الفقهي، الذي أختمه بأبرز النتائج:

أحدها: أن الفقهاء اعتمدوا في ذكر شـروط الإحصــان في باببي حد الزنا

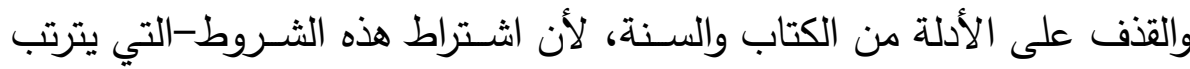
عليها حد من حدود الإسلام - توقيفية لا مجال للاجتهاد فيها.

الثانية: دقة تحري الفقهاء للشروط الصحيحة للإحصان في باببي حد الزنا

الثالثة: أن شــروط المحصــن -الذي يرجم فيه الزاني- التي اتفق عليها

الفقهاء: العقل، والبلوغ، والحرية، والوطء في التبل في نكاح صـحيح، وأما التي

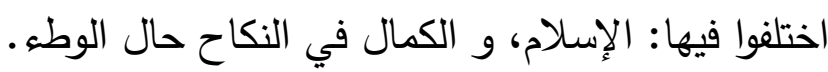

الرابعة: أن الراجح في مسألة اسلام الزوجين للإحصـان في باب الزنا، أنه لا يشترط ذلك.

الخامسـة: أن الراجح في مسـألة الكمال في النكاح حال الوطء للإحصــان

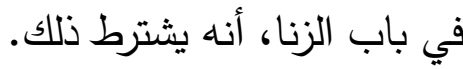

السادسة: أن شروط المحصن -الذي يجلد قاذفه الحر ثمانين جلدة- التي

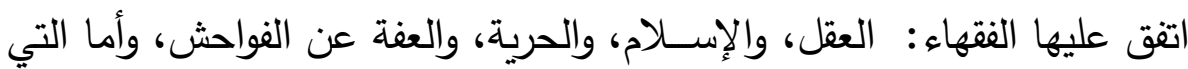

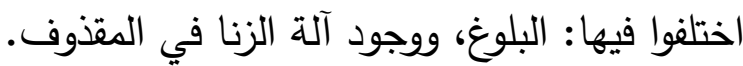


السـابعة: أن الراجح في مســألة بلوغ المقذوف لحصــول الإحصــان؛ أنه

$$
\text { يشترط ذلك. }
$$

الثامنة: أن الراجح في مسـألة وجود آلة الزنا في المقذوف لإحصـانه، أنه لا يشترط ذلك.

أسأل الله تعالى أن يغفر لنا، وأن يبارك لنا فيما تعلهنا، وأن يجمعنا بعلماء

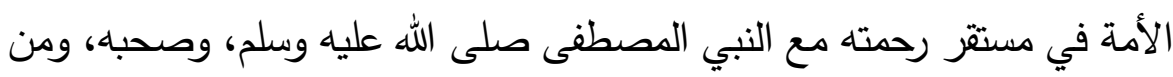
نحبهـم.

وصلى الله وسلم على خير خلق الله أجمعين محمد خاتم النبيين، وعلى النى أصحابه المرضيين، ومن تبع هداهم وأقتفى أثرهم إلى يوم الآخرة والنشور . औ 
فهرس المصادر والمراجع(')

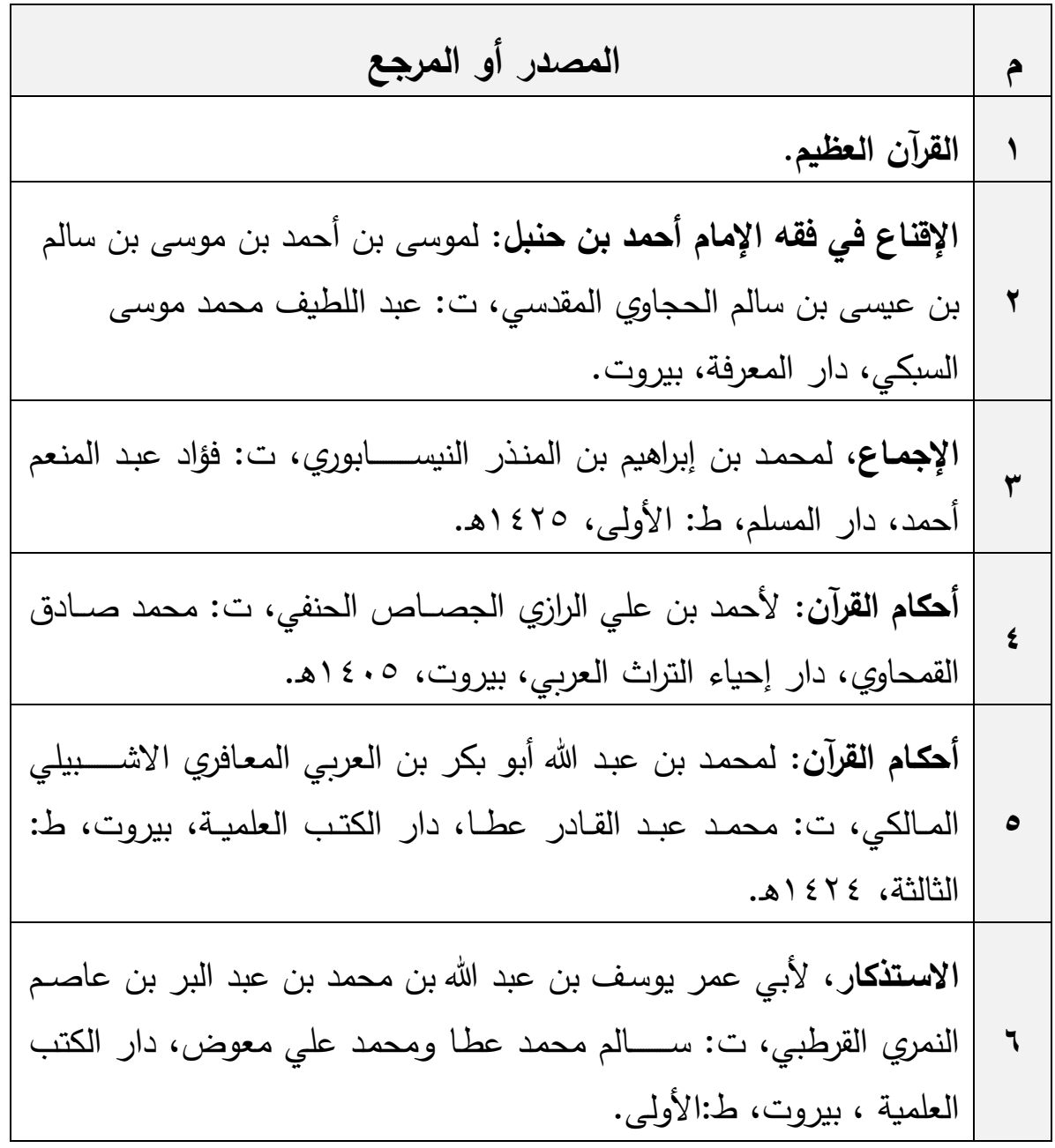

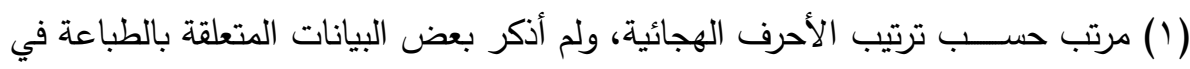
بعض المصادر والمراجح؛ لأني لم أجدها في الكتاب. 


\begin{tabular}{|c|c|}
\hline المصدر أو المرجح & م \\
\hline 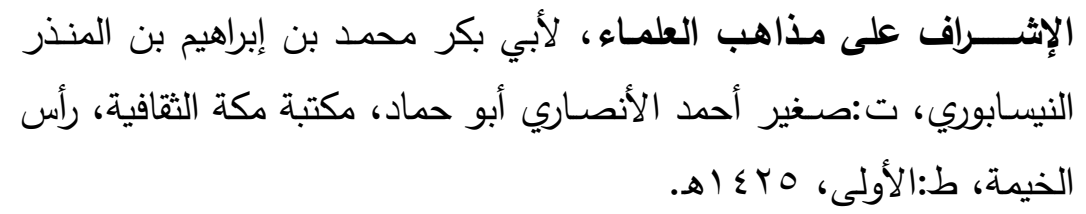 & V \\
\hline 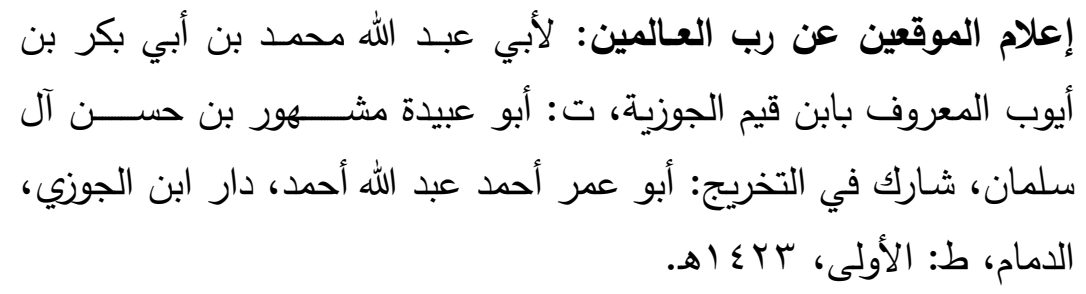 & $\wedge$ \\
\hline 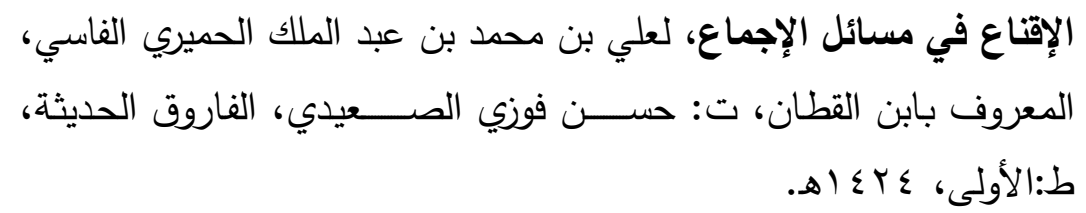 & 9 \\
\hline 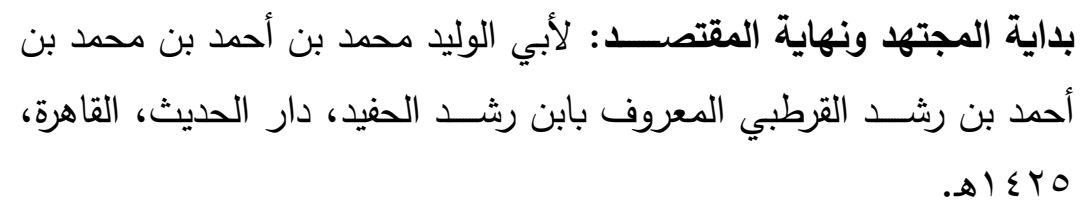 & 1. \\
\hline 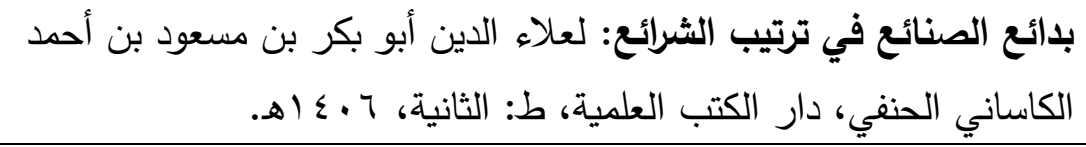 & 11 \\
\hline 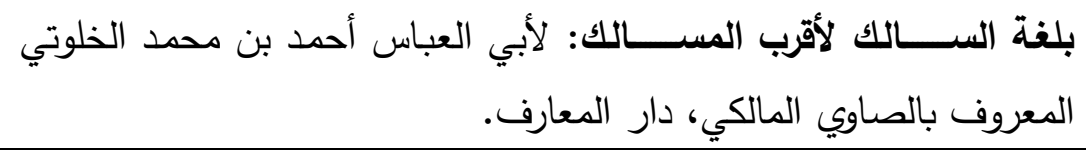 & Ir \\
\hline
\end{tabular}




\begin{tabular}{|c|c|}
\hline المصدر أو المرجع & م \\
\hline 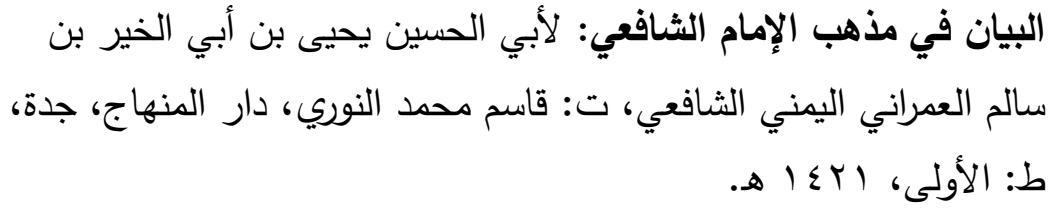 & $1 T$ \\
\hline 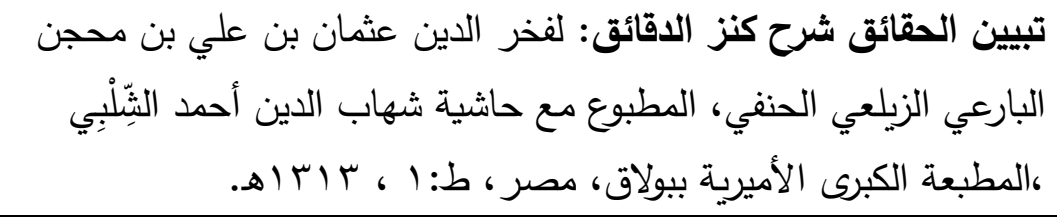 & $1 \varepsilon$ \\
\hline ب شرح المنهاج: لأحمد بن محمد بن علي بن حجر العماء، المكتبة التجارية الكبرى، مصر، & 10 \\
\hline 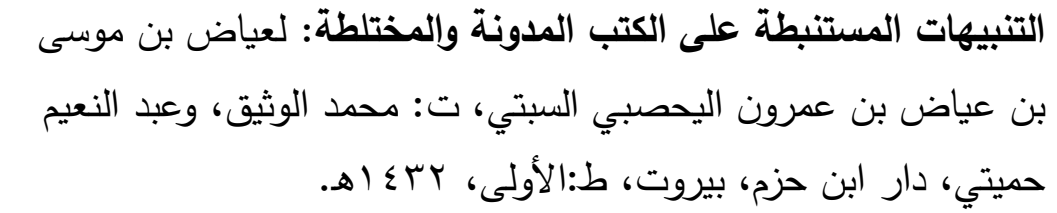 & 17 \\
\hline 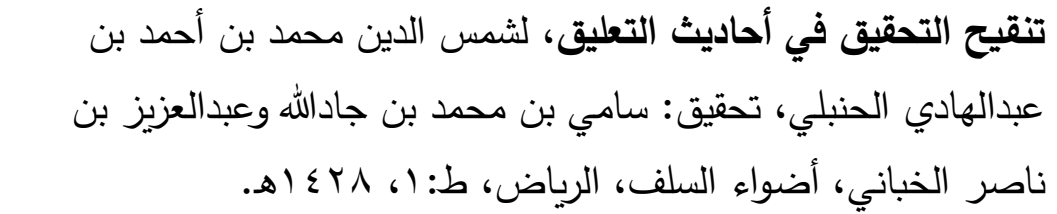 & IV \\
\hline التوقيف على مهمات التعاريف: لزين الدين محمد عبد الرؤوف بن تاج التاجي & 11 \\
\hline
\end{tabular}




\begin{tabular}{|c|c|}
\hline عدر أو المرجع & م \\
\hline 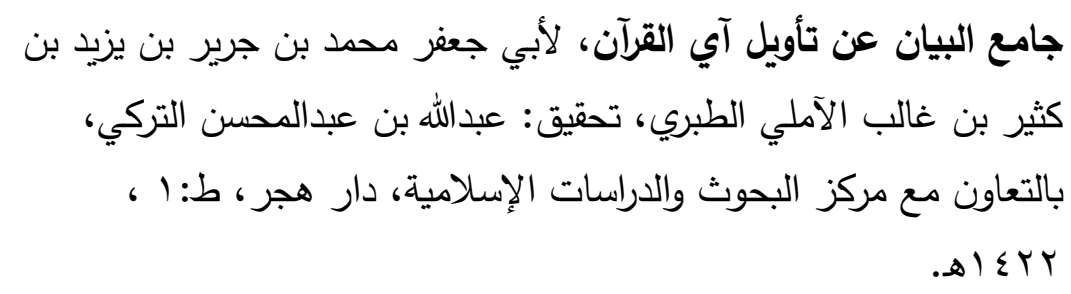 & 19 \\
\hline 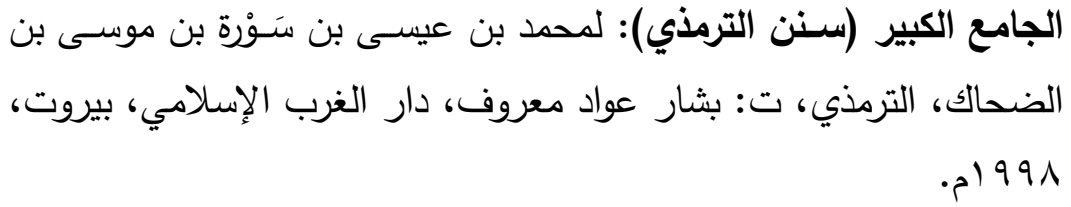 & r. \\
\hline 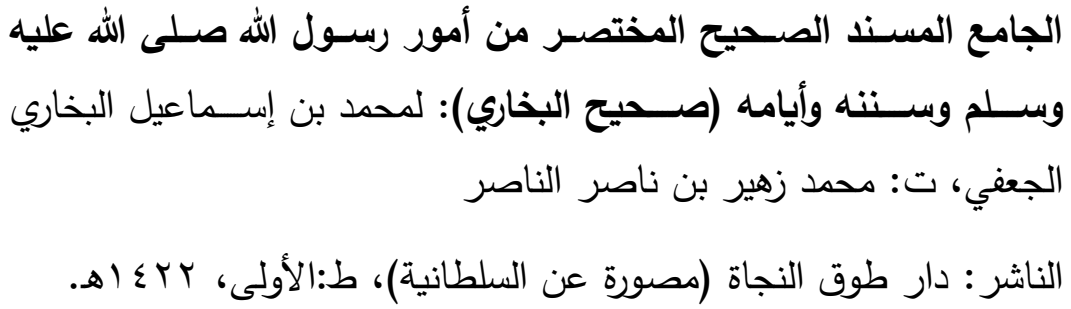 & YI \\
\hline 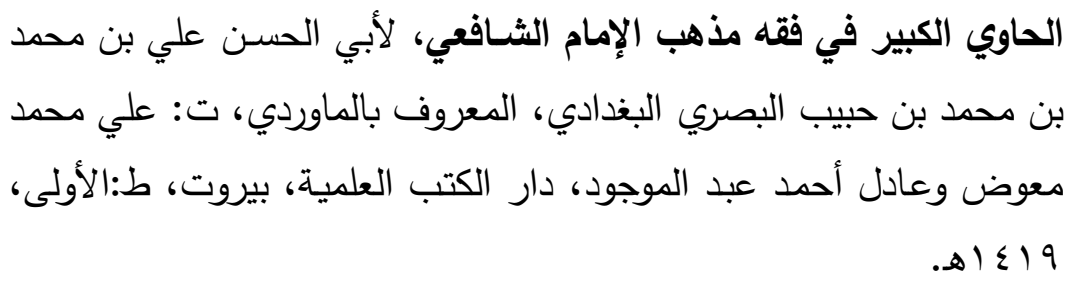 & rr \\
\hline المعروف بالقرافي، ت الثيرة، محمد حجي، الدين أبي العباس أحمد بن إدريس بن عبدالرحمن المالكي & $r r$ \\
\hline
\end{tabular}




\begin{tabular}{|c|c|}
\hline ددر أو المرجح & م \\
\hline 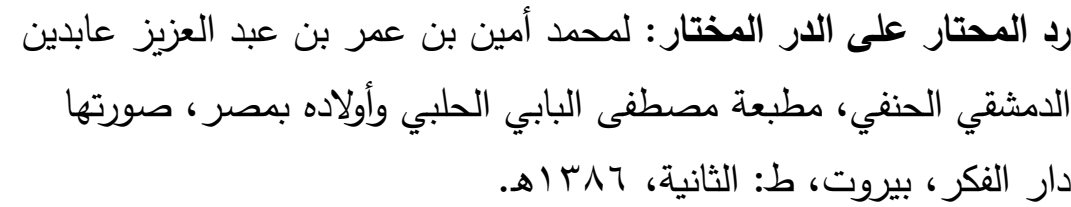 & $Y \leqslant$ \\
\hline 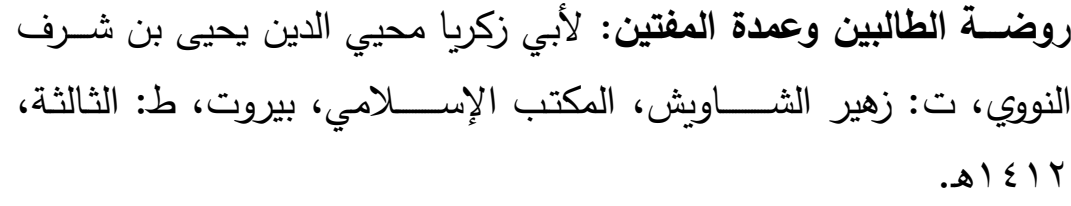 & ro \\
\hline 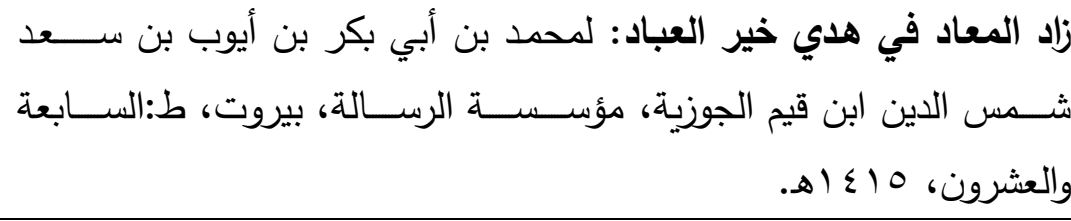 & Yq \\
\hline وآخرون، دار الرسالة العالمية، طالأبي عبد الله محد بن يزيد القزويني، ت: شعيب الأرنؤوط & YV \\
\hline شعَيب الأرنؤوط دآخدو، لأبي داود سـليمان بن الأشـعث الأزدي السـجسـتاني، ت: & Yᄉ \\
\hline 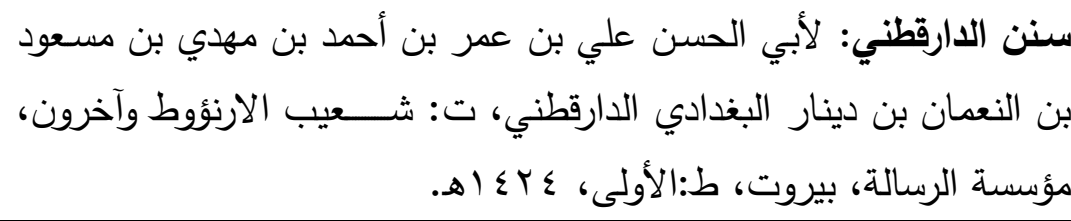 & rq \\
\hline الثطبـرح الكبير على مختصــر خليل، لأبي البركات سـيدي أحمد الدردير ، الثية الدسوقي، دار الفكر. & \\
\hline
\end{tabular}




\begin{tabular}{|c|c|}
\hline المصدر أو المرجع & م \\
\hline الفكر ، بيروت. مختصـر خليل للخرشـي: لمحمد بن عبد الله الخرشـي المالكي، دار & $\mu_{1}$ \\
\hline 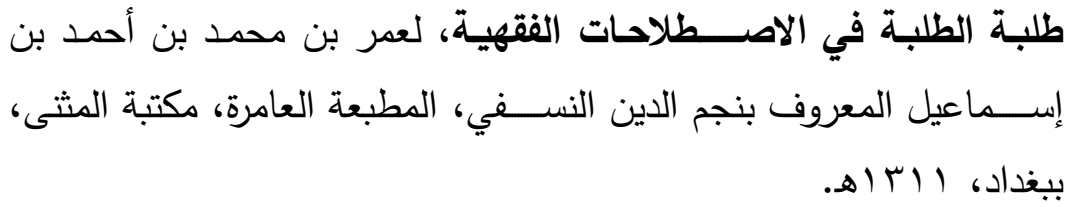 & rr \\
\hline 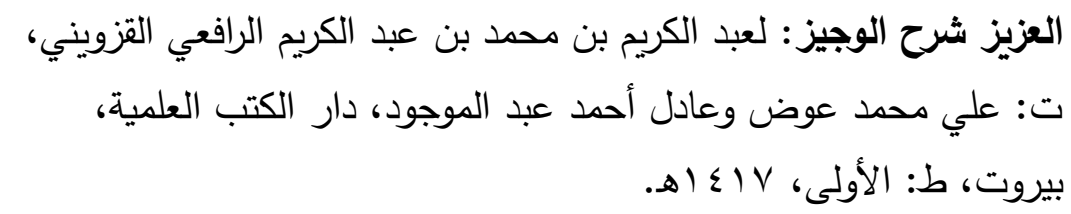 & $r \mu$ \\
\hline 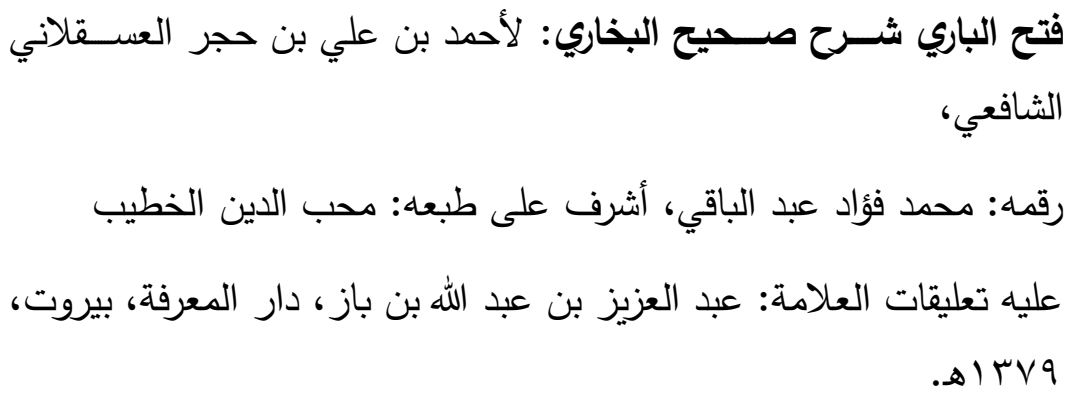 & $r \varepsilon$ \\
\hline والهمام الحنفي، مطبعة مصلى الهداية: كمال الدين محمد بن عبد الواحد، المعروف بابن & ro \\
\hline
\end{tabular}




\begin{tabular}{|c|c|}
\hline صدر أو & م \\
\hline 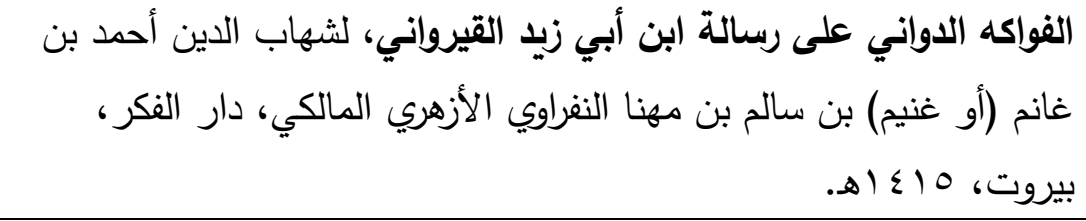 & rq \\
\hline 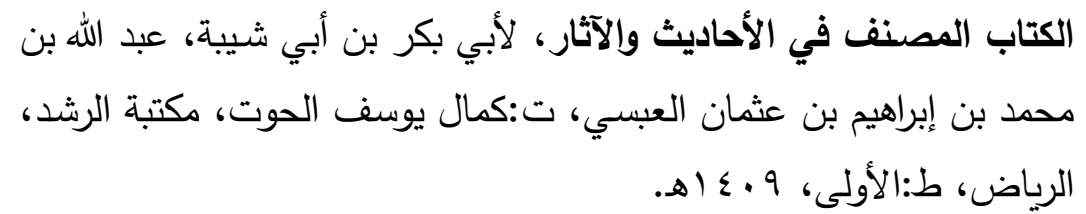 & $r v$ \\
\hline 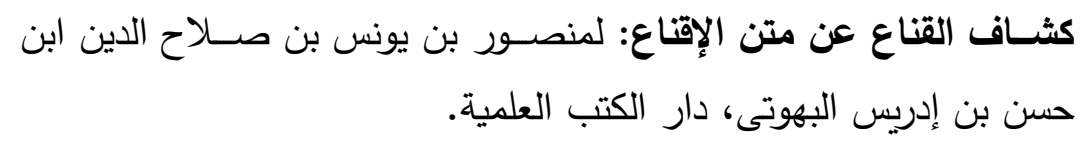 & $r \wedge$ \\
\hline مؤسى الحسيني الكسية معجم في المصطلحات والفروق اللغوية، لأبي البقاء أيوب بن الحنفي، تحقيق: عدنان درويش ومحمد المصري، & rq \\
\hline بعض العلماء، دار المعرفة، لبيروت، الأئعة محد بن أحمد بن أبي سهل السرخسي، تصحيح & $\varepsilon$. \\
\hline 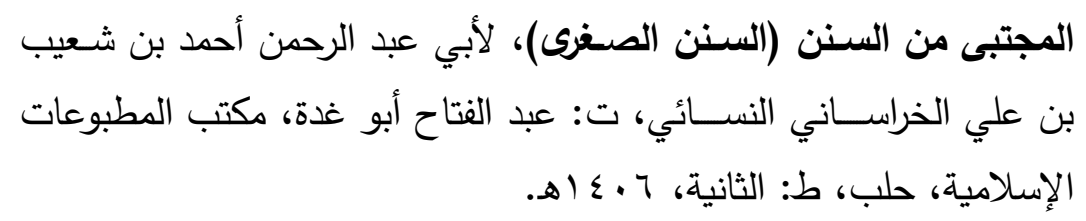 & $\leqslant 1$ \\
\hline القرطلى بالآثار: لأبي محمد علي بن أحمد بن ســـيد بن حزم الأندلســـي & $\varepsilon 0$ \\
\hline
\end{tabular}




\begin{tabular}{|c|c|}
\hline المصدر أو المرجع & 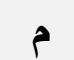 \\
\hline مراتب الإجماع في العبادات والمعاملات والاعتقادات، لأبي محمد علي بن & $\varepsilon 7$ \\
\hline 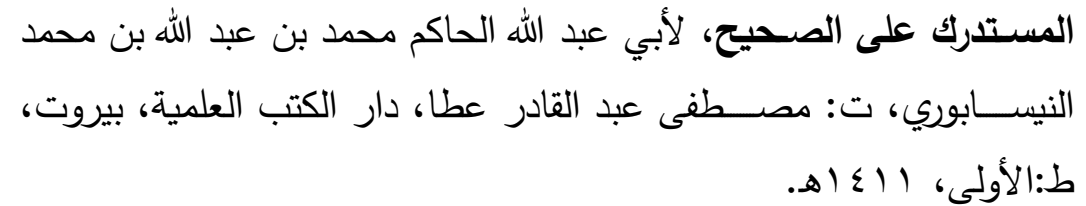 & $\leqslant V$ \\
\hline مســــــ الإمـام أحمد بن حنبل: لأحمد بن محمد بن حنبل، ت: شــــيب & $\leqslant \wedge$ \\
\hline 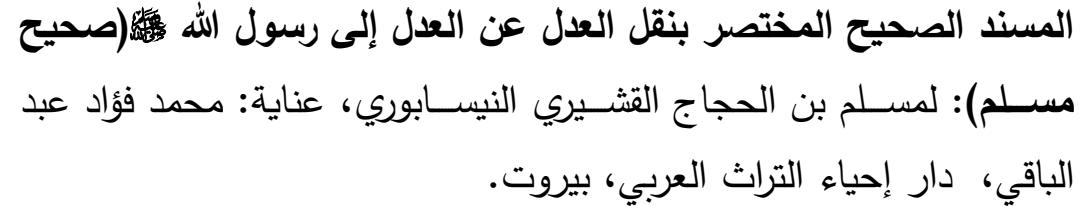 & $\varepsilon 9$ \\
\hline الطبانية. المجبم الكبير: لســليمان بن أحمد بن أيوب بن مطير اللخمي الثـــــي & 0 . \\
\hline المقني، لموفق الدين أبي محمد عبدالله بن أحمد بن محمد بن قدامة، المقال & 01 \\
\hline
\end{tabular}




\begin{tabular}{|c|c|}
\hline المصدر أو المرجع & 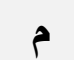 \\
\hline المبراهيم القرطبي، لما أشكل من تلخيص كتاب مسلم: لأبي العباس أحمد بن عمر بن & or \\
\hline والنجار، تهى الإرادات، لتقي الدين محمد بن أحمد الفتوحي الحنبلي الشهير بابن & or \\
\hline منح الجليل شرح مختصر خليل: لمحمد بن أحمد بن محمد عليش المالكي، & $0\}$ \\
\hline 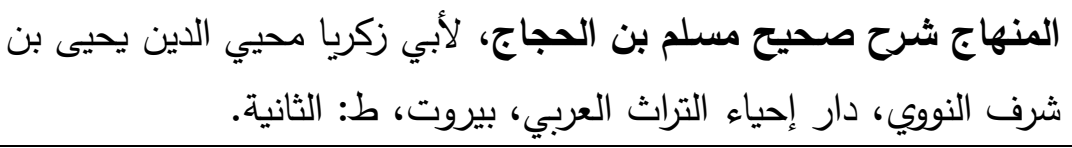 & 00 \\
\hline 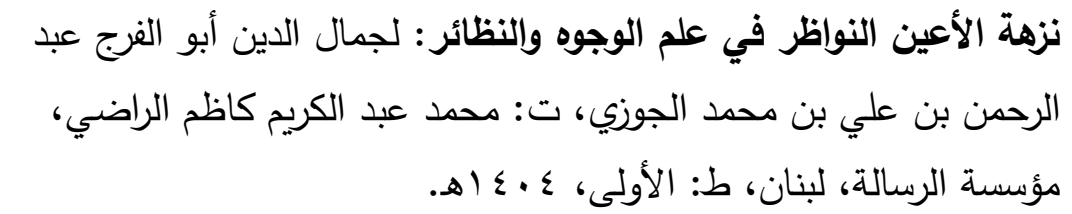 & 04 \\
\hline 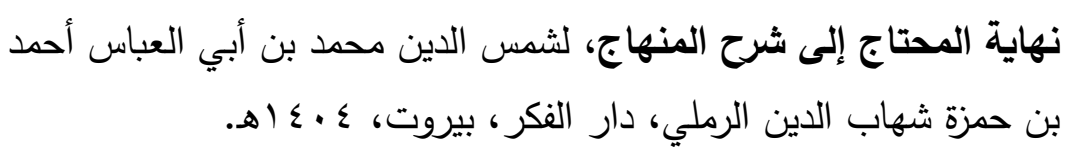 & $O V$ \\
\hline
\end{tabular}


فهرس الموضوعات.

\begin{tabular}{|c|c|}
\hline الصفحة & 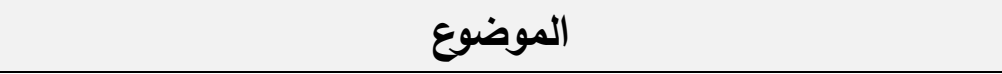 \\
\hline $1 \wedge 9 V$ & المقدمة المقة \\
\hline $19 \cdot \varepsilon$ & المبحث الأول: تعريف الإحصان. \\
\hline 19.7 & المبحث الثاني: شروط الإحصان في باب حد الزنا. \\
\hline $19 \cdot v$ & المطلب الأول: شروط الإحصان المتقق عليها في باب حد الزنا. \\
\hline $19 \cdot v$ & الشرط الأول والثاني: أن يكون بالغا عاقلا. \\
\hline $19 \cdot 1$ & الثرط الثالث: أن يكون حرا، فلا يكون محصنًا من نكح أمة. \\
\hline 19.9 & الثرط الرابع: أن يكون الوطء في نكاح. \\
\hline 1911 & الثرط الخامس: أن يكون الوطء في نكاح صحيح. \\
\hline 1911 & الثرط السادس: أن يحصل الوطء في القبل. \\
\hline 1914 & المطلب الثاني: شروط الإحصان المختلف فيها في باب حد الزنا. \\
\hline 1914 & الشرط الأول: إسلام الزوجين. \\
\hline 1919 & الشرط الثاني: الكمال في النكاح حال الوطء. \\
\hline $19 r r$ & المبحث الثالث: شروط الإحصان في باب حد القذف. \\
\hline
\end{tabular}


(عدنان بن عبدالله بن على المالكي)

شروط الاحصان عند الفقهاء

\begin{tabular}{|c|c|}
\hline الصفحة & الموضوع \\
\hline I qru & المطلب الأول: شروط الإحصان المتفق عليها في باب حد \\
\hline $19 r r$ & الشرط الأول: أن يكون عاقلا، فلا يحصل الإحصان من مجنون. \\
\hline $19 Y \varepsilon$ & الشرط الثاني: أن يكون مسلما. \\
\hline 1940 & الشرط الثالث: أن يكون المقذوف حرا، فلا يكون الإحصان من \\
\hline $19 Y V$ & الشرط الرابع: العفة عن الزنى. \\
\hline $19 r 9$ & المطلب الثاني: شروط الإحصان المختلف فيها في باب حد. \\
\hline $19 r 9$ & الشرط الأول: بلوغ المقذوف. \\
\hline I 9 rr & الشرط الثاني: وجود آلة الزنا في المقذوف. \\
\hline 1949 & خاتمة البحث \\
\hline $19 \% \wedge$ & فهرس المصادر والمراجع. \\
\hline $19 \leq V$ & فهرس الموضوعات. \\
\hline
\end{tabular}

$-19 \leqslant 1-$ 